\title{
السرد الشعري في القصيلة العربية القديمة
}

\section{وكتور/ خالد بنا ناصر الجميحيا القحمانيا}

جامعة الباحة

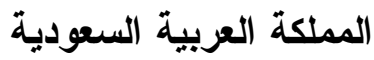

ينفتح النص الإبداعي على ألوان مختلفة من الأجناس الأدبية فتتمثل القصة في

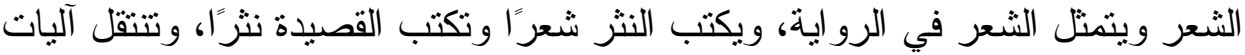

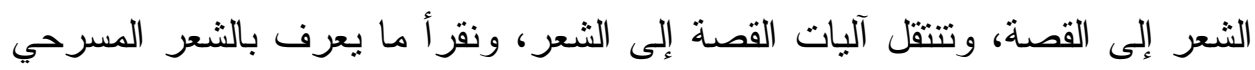

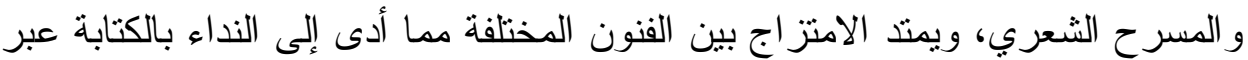

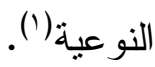

و العلاقة بين الثعر و السرد في الإبداع "يحدث تبادل في المواقع أو تداخل بين الخصائص فإذا الثعر نثر إذا كان نظمًا، و إذا النثر شعر إذا كان مشبعًا بالصور ، مُتُقًا

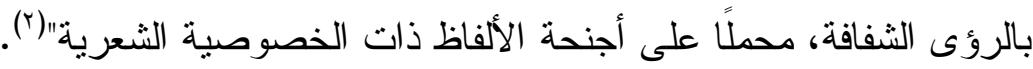

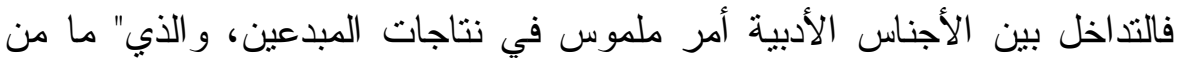

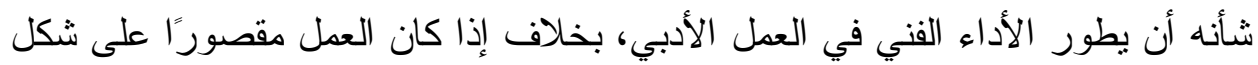

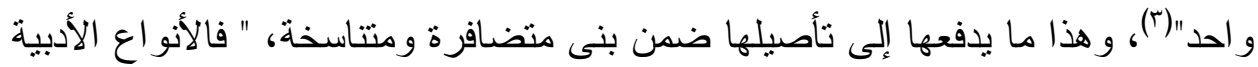
لا تتطور فقط، ولكنها على طريق تطورها تنتاسخ وتتحور إلى أنو اع أخرى نتيجة

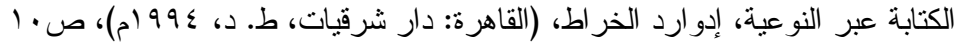

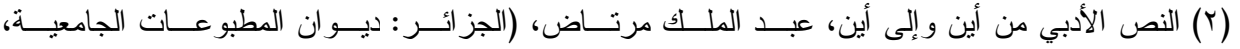

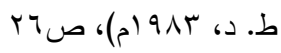
(ץ) تداخل الأجناس الأدبية في الرواية الجز ائرية المعاصرة- الكنابة ضد أجنسة الأدب، أ. د دياب قديد، (تداخل

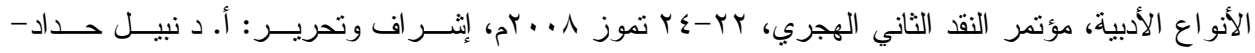

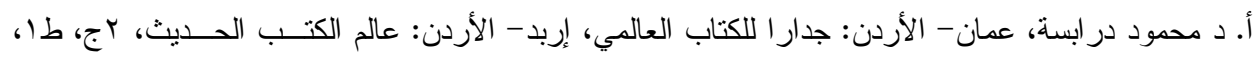

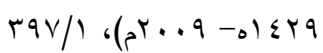


لتغير المجتمع، واجتهاد عبقريته في خلق أثنكال شتى منسجمة مع الميول والأوضاع

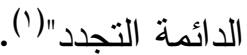

ومر احل التقاطع بين الأجناس النثرية والثعرية " منطقة تمتص سمات السردية الروائية أو القصصية في الوقت الذي تمتص فيه سمات الثعرية الغنائية، فهي منطقة

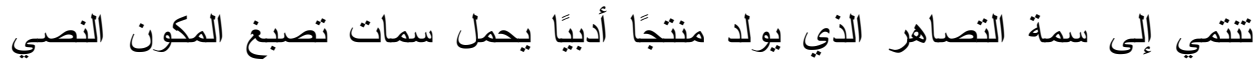

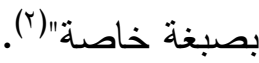

ثم إن السرد و الثعر جنسان منقاربان، فـ"القصة حين تستقدم إلى عالم القصيدة

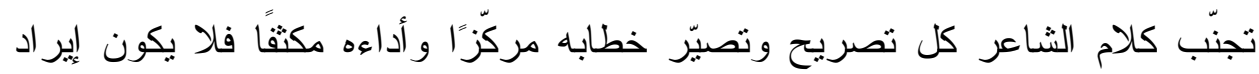

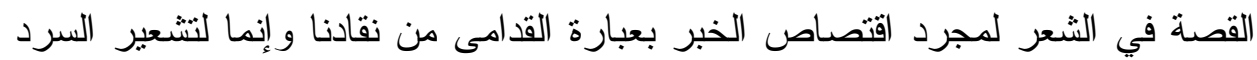

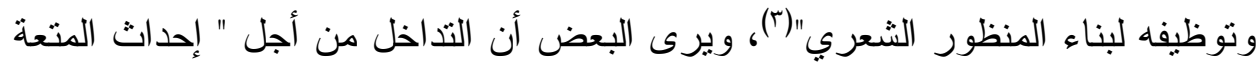

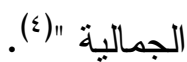

و التمازج بين الثُعر والسرد تمازج قديم فأرسطو وضع القص ضمن الثعر

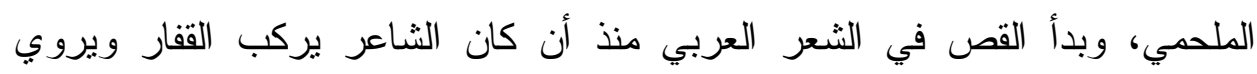

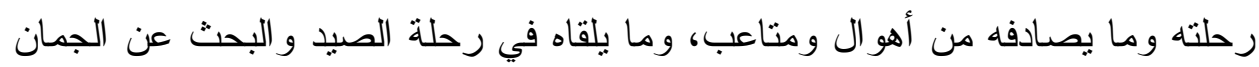

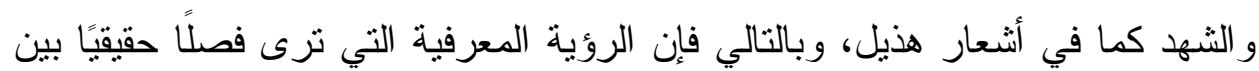

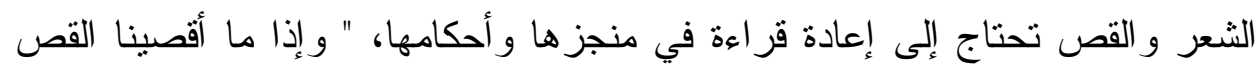

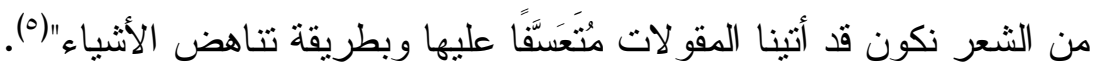

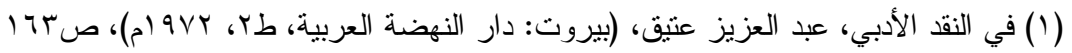

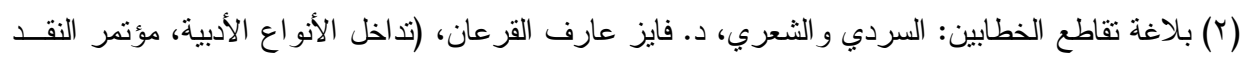

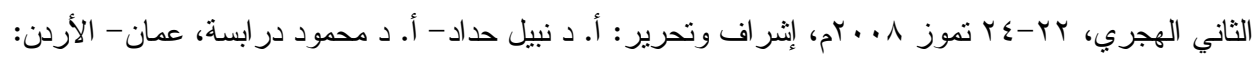

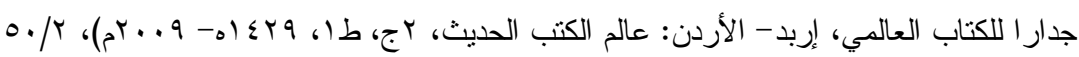

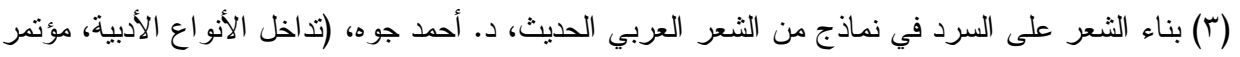

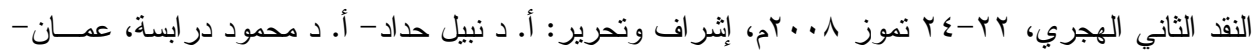

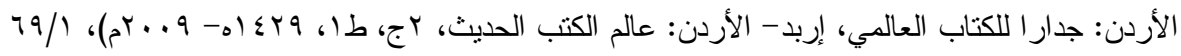

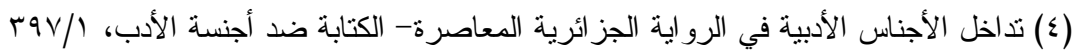

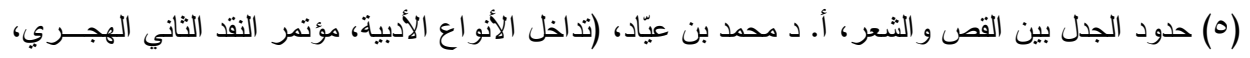

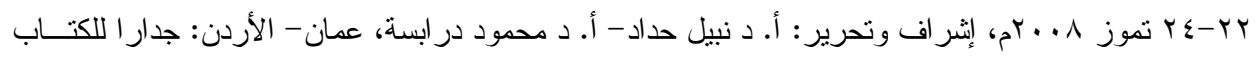

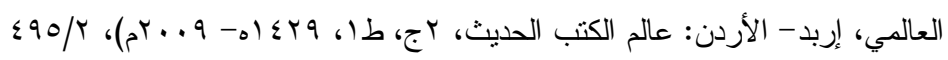


و المتأمل في القصيدة العربية القديمة يلحظ أنها مع اتصال مباثر مع السرد أو ما

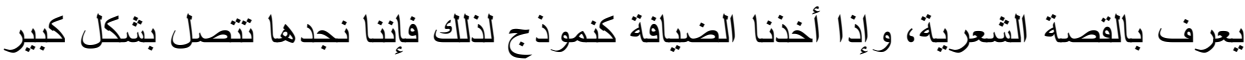

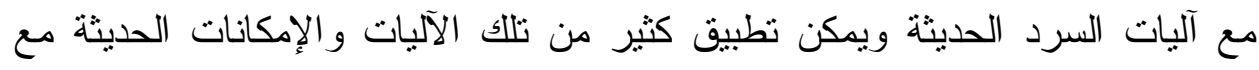
النص الثعري القديم. فالضيافة بمفهومها الذي يدل على القرى وتقديم الأكل وما يلزم من مآدب العرب

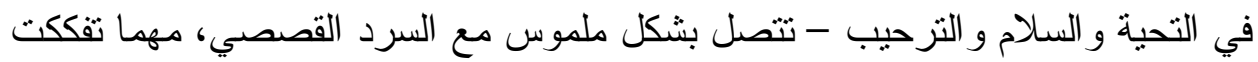

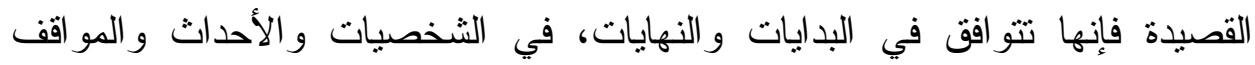
و الحو ارات و الحبكات و التعاقبات المكانية و الزمانية، فكلها تشعرنا أننا أمام قصة فيات حياتية محكية يرويها لنا الشعر اء بعناية وإحكام، تتضح معالمها في أحداثها المتسارعة

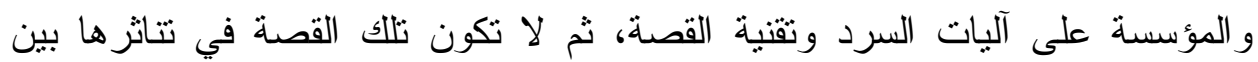
قصائد متعددة بل يؤسس الشعر اء تلك الأحداث في قصائد شعرية معينة يحكمها وزن ونه فئه و احد وقافية واحدة، مما ينقلنا إلى قصة يحكمها زمان ومكان معنيان بقصة في و اقعة محدة.

و على ضوء ذللك، سنتناول البناء السردي لشعر الضيافة بناء على مبحثين، الأول: عناصر البناء السردي، و الثاني: الزمن السردي. 
المبحث الأول: عناصر البناء السردي.

في قصبدة الضيافة تتوفر آليات السرد التي نعتادها عادة في أجز اء القصة، من الناء الاهن شخصية وحدث وحوار وحبكة، ومن تللك الآليات التي كانت بارزة بشكل ملحوظ: الشخصية وتعلقها بالظروف وبشخصية السارد، و الحو ار ، و الحدث و والحبكة الفنية.

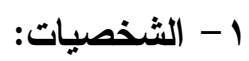

يتميز البناء السردي في القصيدة القصصية أنه حامل للشخصية، إذ تعد الثخصية

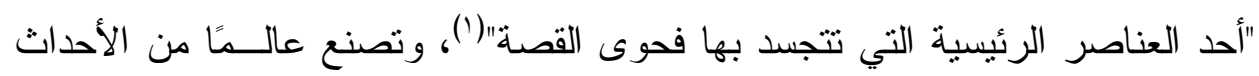

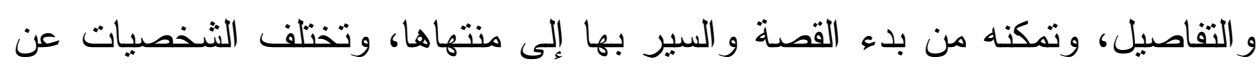
بعضها البعض، فهي تأتي في القصيدة القصصية في ظهورها ضمن أبعاد التصور الجسماني و الاجتماعي و النفسي، و الأبعاد التي تصور الثخصية فئية من زوايا متعددة،

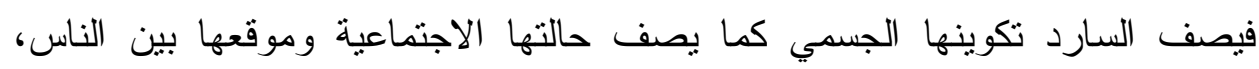

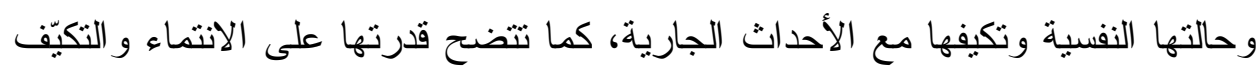

$$
\text { مع الواقع الذي يدور من حولها. }
$$

و الثخصية ذو نمطية مختلفة فنجد الثخصية الجوهرية والثخصية الثانوية، و الثخصية المحورية هي الثخصية الفاعلة في المشهد القصصي، و المنسمة بالنفاذ في الأشياء و القادرة على التغيير، و وتقليب المواقف، والثخصية الثانوية هي الثخصية

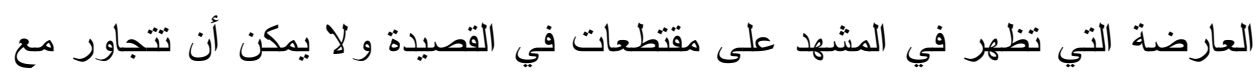

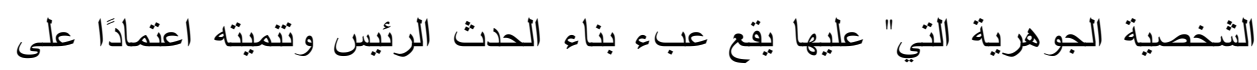
صفاتها، وقد كان يطلق على منل هذه الشخصية مصطلح البطل"(؟).

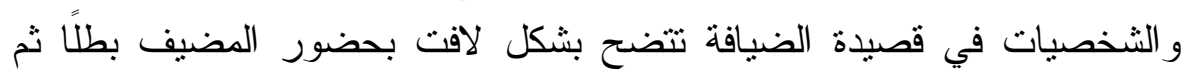
يأتي الضيف تاليًا، و الضيف و المضيف شخصيتان رئيسيتان في البناء السردي لقصيدة الضيافة، ففي قصيدة ضيافة الصداقة شخصية الضيف تبدو شخصية إنسانية ضعيفة

(1) الوجيز في دراسة القصص، لين أولتيرند، ترجمة: عبد الجبار المطلبي، (بغــداد: دار الــشؤون الثقافيـة، 

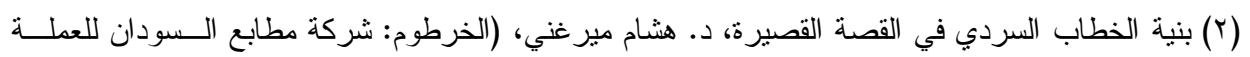

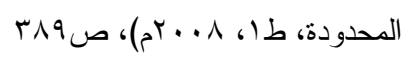


محتاجة طلبية بينما شخصية المضيف شخصية قوية بطولية ملبية. ومما يمكن أن يسلط الضوء على مثل تلاك الشخصيات، قول الأبيرد الرياحي ('):

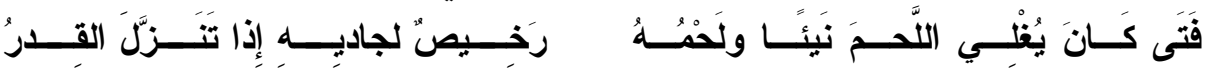

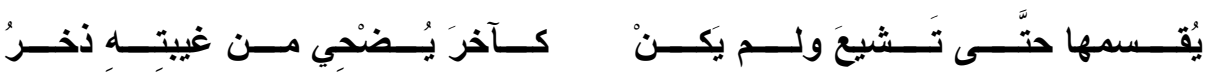

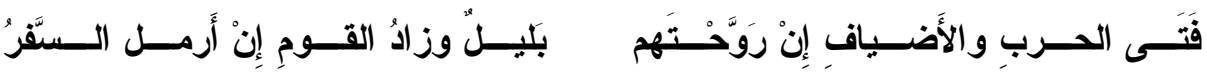

فالثاعر حدد شخصية المضيف شخصية دهيمنة على المشهر وهي الثخصية القوية التي تتمتع بصفات جيدة، بينما شخصية الضيف فهي شخصية تستعطف وخالية من الطعام، وتنظر إلى الطرف الثاني بعين الضعف و انتظار العطاء. ومن جانب آخر نجد شخصية الضيف تبدو شخصية مزدوجة إنها تحمل نمطين من التركيب، فهي تحمل نمط الضعف والحاجة كما تحمل نمط القوة و الثورة و الاعتز از، وهي ما تتطابق مع صورة الصعلوك، الذي يتماتل لنا على هيئة الضيف

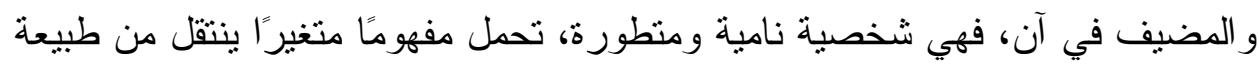

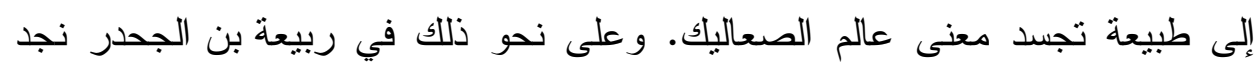
شخصية الأضياف شخصية الجياع وشخصية الصعلوك شخصية المضيف القوي المعتد بنفسه (r)

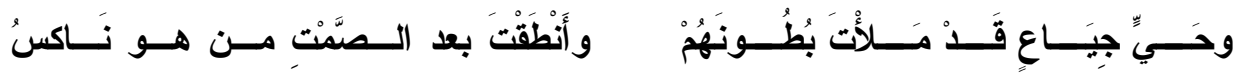
وفي قصيدة البخل، يحتل الضيف شخصية العدو بينما يحتل البخيل شخصية المضيف العدائي الذي يعادي الضيف، ومما قاله الشعر اء في قصيدة البخل أن شخصية لئلة ( (1) ديوان الأبيرد الرياحي، ضمن كتاب شعر اء أمويون، دراسة وتحقيق: د. نوري حمودي القيسي، (بغـــاد:

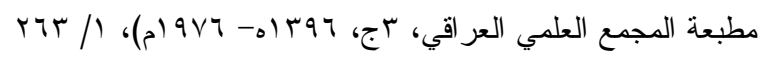

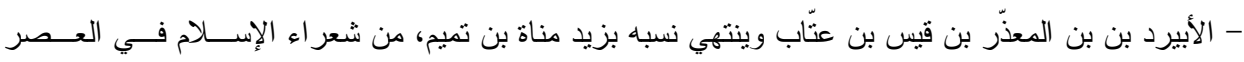

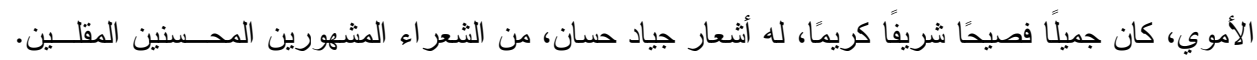

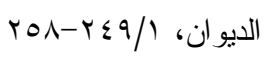

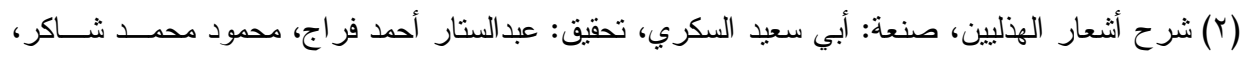

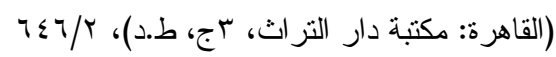
- لم أجد له ترجمة سوى أنه من شعر اء هذيل الصعاليك، أورد له له السكري أبيات قليلة يغزو فيها بني فهم. 
البخيل شخصية ظالمة للضيف بينما هي ليست ظالمة لما تتفق، وذلك في قول

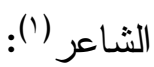

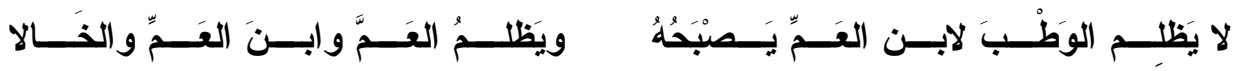
و الثخصية في البناء السردي شخصية تبدو في واقع لا تتأثز بالظروف أو شخصية تتبادل تأثنير الظروف أو شخصية تقهرها الظروف فتفقد حضورها، أو فئية شخصية تعدلها الظروف، أو شخصية تخضع للظروف فلا تبدي أي مقاومة(؟)،

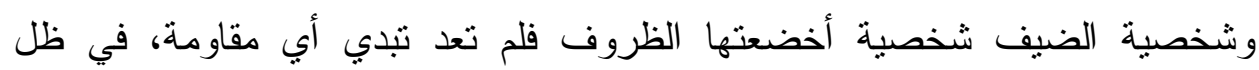

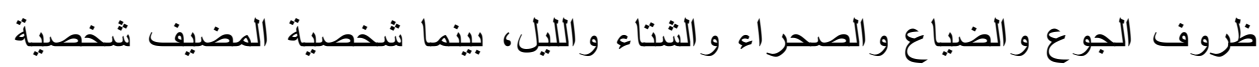
من النوع الأول إذ تتسم بطبيعة لا تخضع للظروف وإنما تتموضع في تجاوز تللك الظروف و الحلول في مقام التجاوز و الإخضاع.

وشخصية الصعلوك مبادلة لتالك الظروف و الوقائع فهي تتأثز وتؤثر مع تأثنير ها البارز على الظروف و العقبات، و هذه الثخصية " يثي بشخصية قاص متمرد ثائر ،

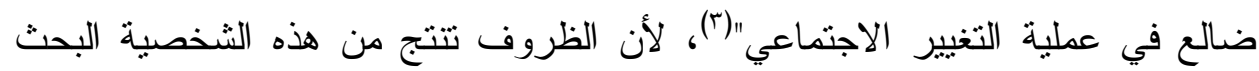

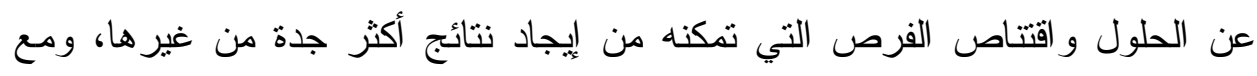

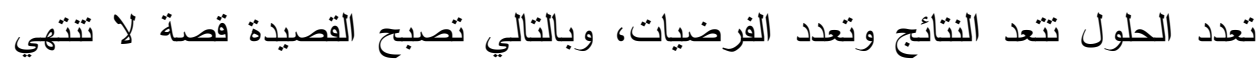
ومو اقف كلما تعددت كلما صنعت أحداثًا كثيرة. ثم يتضح لنا أن الشعر اء نوّعوا بين شخصيات البناء السردي، ووقفو الثلى على كافة التعددية لها بما يتفق مع سياقات القصة الشعرية وموقف الضيافة، مما أدى إلى حملها لئاء

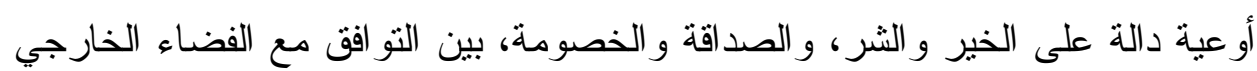
أو الصر اع معه.

(1) الأشباه و النظائر - من أثتعار المتقدمين و الجاهليين و المخضرمين، للخالديين: أبي بكر محمد و أبي عثـــان

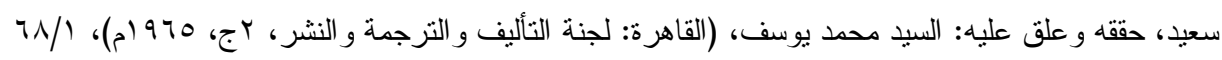
- غير منسوب. (r) ينظر : الثخصية و البيئة في القصة القصيرة، ثابت ملكاوي، (الإمار ات: أبحاث الملنقى الثـاني للكنابـات

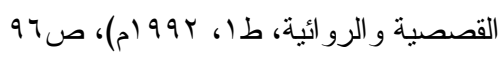

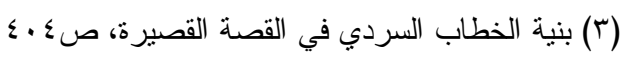


و الثخصيات الثانوية لا تعدو أن تكون شخصية مساندة تقوي مشهد الضيافة وتقف بجانب المضيف في تلبية طلبات الضيف، وتظهر تللك الشخصيات كما يبدو في

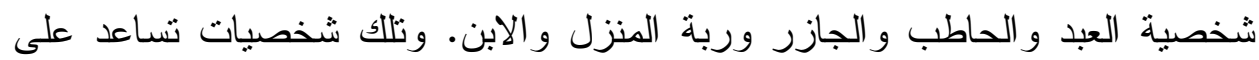
نمو الحدث وتقويته وبيان خفايا شخصية المضيف، و التفاف أكثر على شخصية ونى ولثية

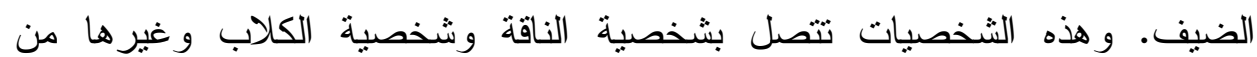
الثخصيات المساندة، وذلك منل قول الثـاعر في شخصية الناقة (1):

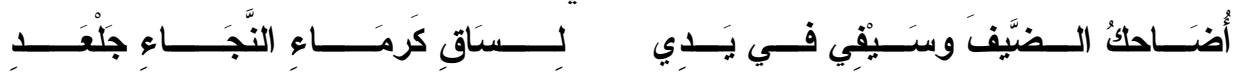
فالثاعر بكثف عن شخصية الضيف و المضيف، وهما شخصيتان رئيسيتان، وشخصية الناقة شخصية ثانوية، يتتامى الحديث من خلالها ويقوي المشهد ويدعم الموقف.

\section{r}

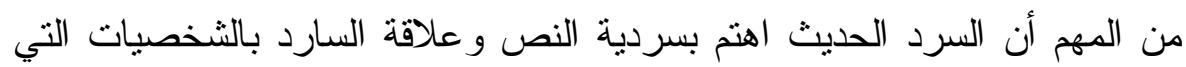

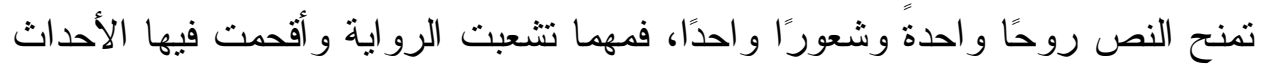

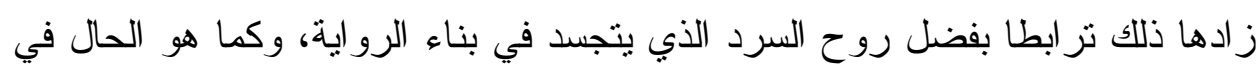
بناء القصيدة إذ يتمثل بناء القصيدة إلى شيء من الروح دوح الو احدة التي يمنلها السرد.

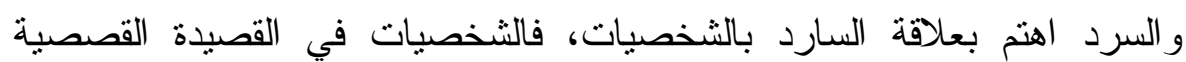
ترتبط بكيفية تقديمها للمتلقي وعلاقتها بالثاعر وذللك من خلال الصيغة السردية الذاتية،

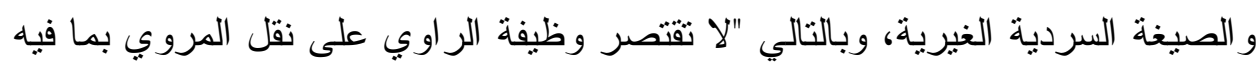

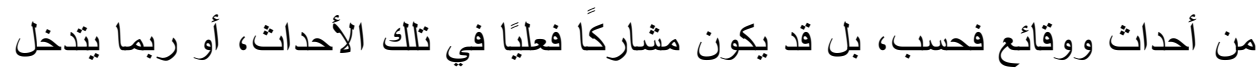

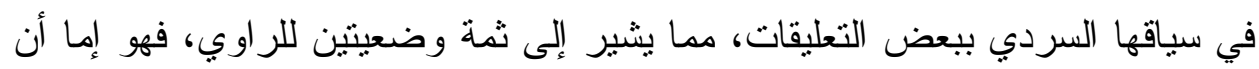
يكون خارجًا عن نطاق الحكي أو أن يكون داخل نطاق الحكي" (؟).

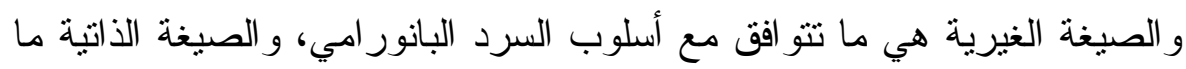

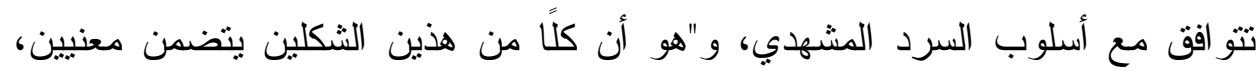

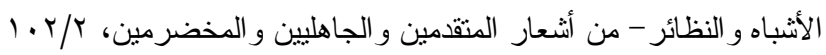
- بدون نسبة. (r) بنية النص السردي من منظور النقد الأدبي، د. حميد محمد لحمداني، (بيروت: المركز الثقــافي العربـي، 
فالأسلوب البانور امي يتضمن الحكي و الرؤية الخلفية (الراوي / الثخصية) ، و الأسلوب

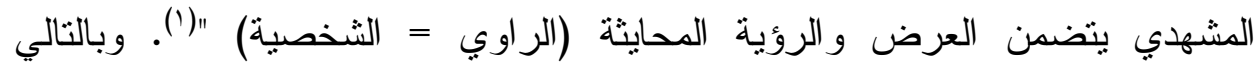
فالثاعر في الأسلوب المشهي هو من يقوم بفعل الضيافة، فعندما يصف مشهد الضيافة يصف المشهد بمر آة ناقلة، وبمحاكاة للموقف، وتعبر تلك التداخلية في المشهد بتطوير

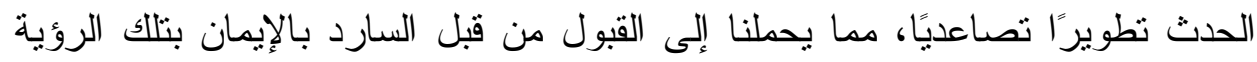
الفكرية أولًا ثم بناء الشخصية من حدث تُ إلى حدث آخر حتى يصل الموقف إلى الغاية ثم الخلاص. بينما يقف السارد في الأسلوب البانور امي على مشهد القصيدة في تحريك

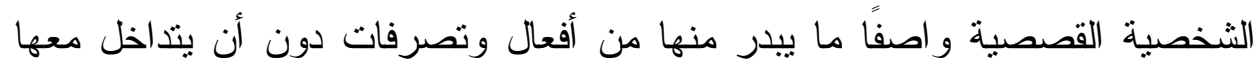

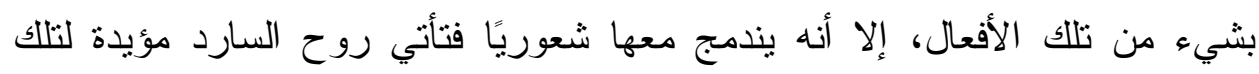

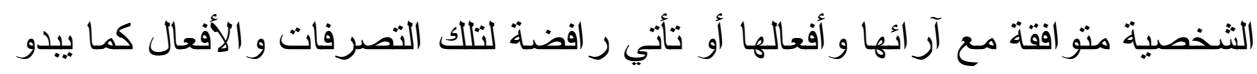
في البناء السردي لقصيدة البخل. وقصيدة الضيافة تهنم في سرد القصة بأسلوب الضمائر، فالأنو اع السردية تحتفي

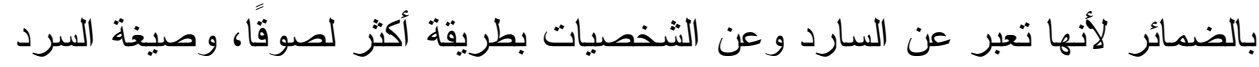

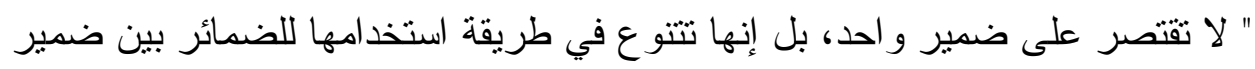
المنكلم وضمير الغائب وضمير المخاطب، وقد يجمع الراوي بين هذه الضمائر في عدة ولني مقاطع من القصة ذاتها، أو حتى في مقطع واحد فقط"(؟).

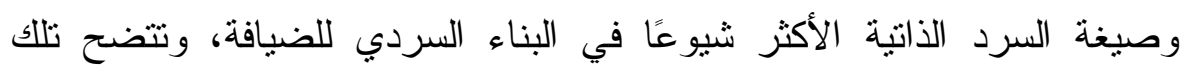
الصيغ على وجه التحديد في حديث الثعر اء عن المضيف، حينما يتحدثون عن القوة المتمنتة في المضيف، فيكرّس ضمير المتكلم بشكل لافت، وكما يقول جير ار جينت

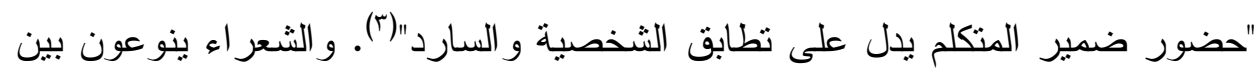

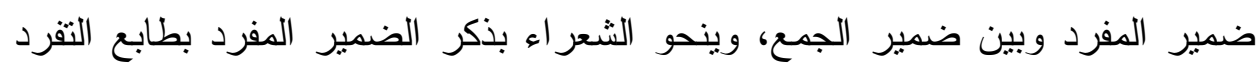

(1) مقو لات السرد الأدبي، تزفتتان تودوروف، ترجمة: الحسين سحبان - فؤ اد الصفا، (آفاق المغـرب، العـدد

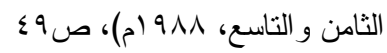
( ا) تقنيات السرد وآليات نتكيله الفني - در اسة نقدية، د. نفلة حسن العزي، (عمّان: دار غيداء للنشر و التوزيع،

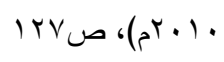

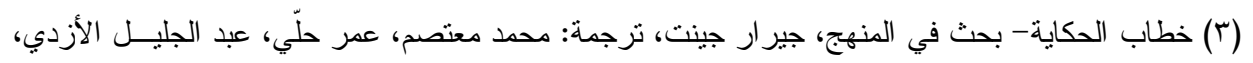

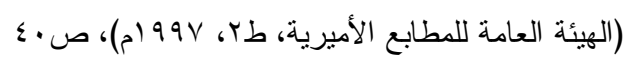


عن الآخرين، مما يعني أن تنويع الثاعر في بناء القصة يحكي عن انتقال في آليات

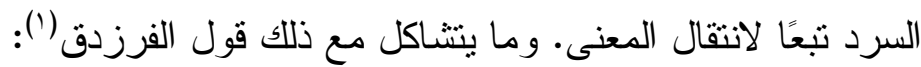

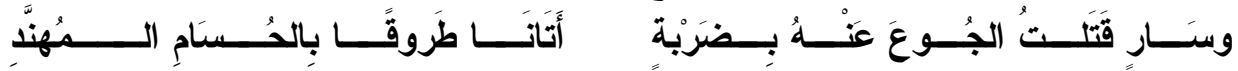
فالثاعر يذكر فعل الضيافة في ضمير المفرد في كلمة (قتلتُ) بينما قدوم الضيف

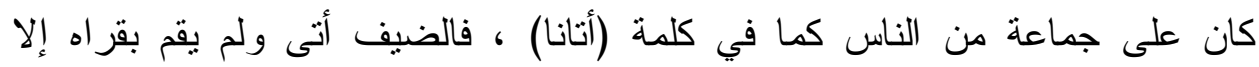
المضيف الكريم الذي تفرّد عن بقية الناس.

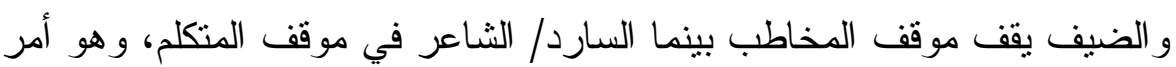
مشاع في قصائد ضيافة الصداقة، أو ما يرفع من شأن المتحدث في تبيان قيمة الثجاعة

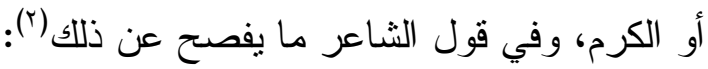

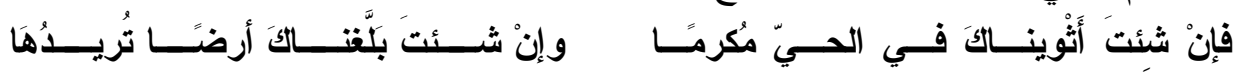
ولا يقف السارد في موقف المتحدث مهملًا موقف المخاطب، متلبسًا شخصية

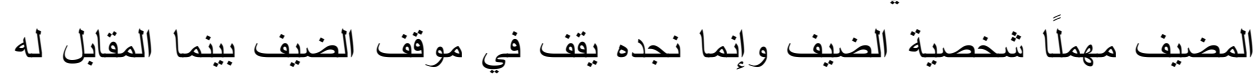
موقف الضيف، وهذا قليل بالنسبة لعلاقة الثاعر بالمضيف و ابتعاده عن شخصية الضيف، ومثل هذا يكثر في قصائد البخل بخلاف القصائد التي تعنى بالصداقة، كالذي بأي

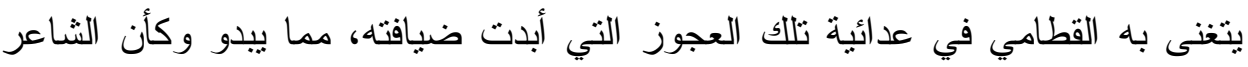
يأخذ مسافة عن علاقته بمثل هذا الموقف من المضيف الذي تجرّد من صداقته، وبهذا

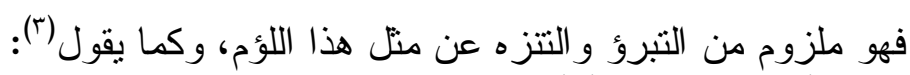

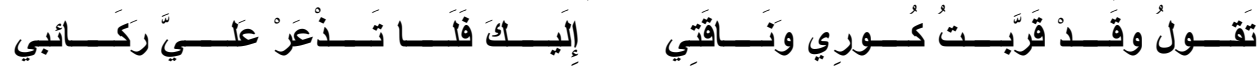

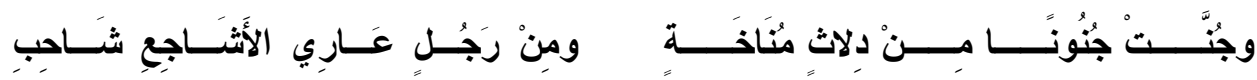
(1) شرح ديو ان الفرزدق، ضبط معانيه وشروحه و أكملها: إيليا الحاوي، (بيروت: دار الكتاب اللبناني للطباعة

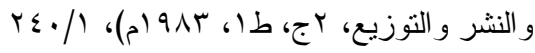

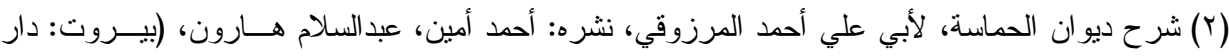

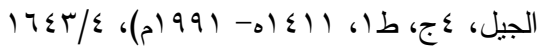
- بدون نسبة.

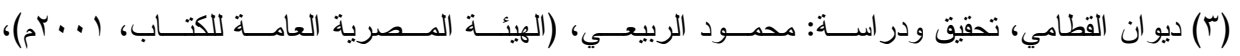
صـ 


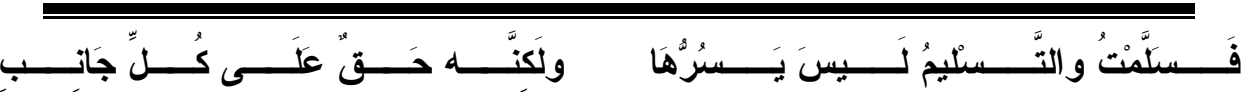

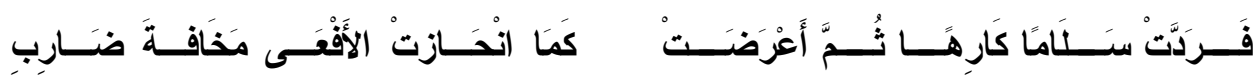

ويتكرر كثيرًا حينما يتمركز السارد في موقع المضيف، فإن موقف الضيف يتمثل مئل

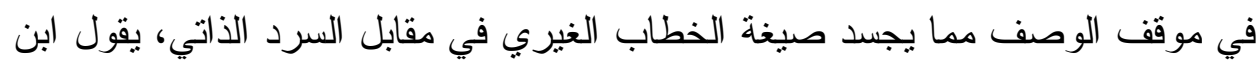

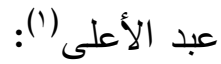

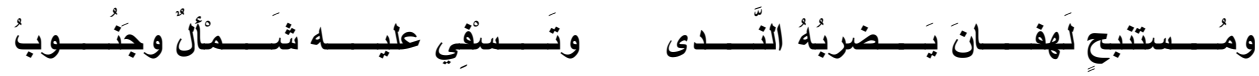

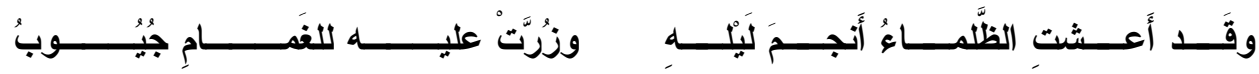

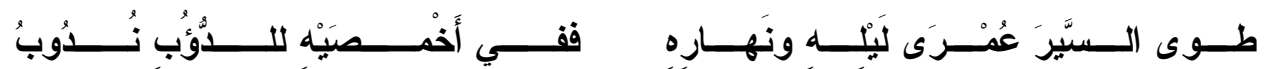

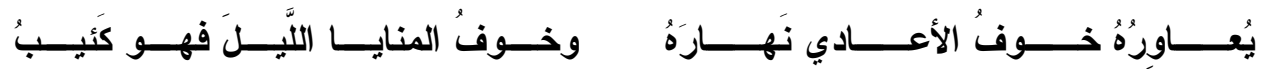
و الثعر اء يستخدمون الصيغة الذاتية و البانور امية في بنائية النص الواحد، وهو

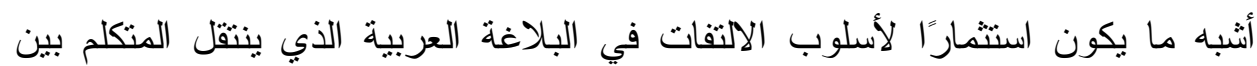

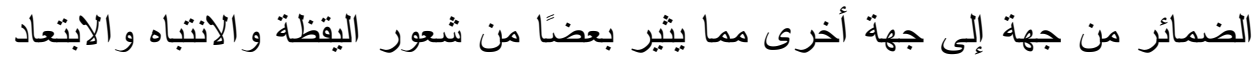

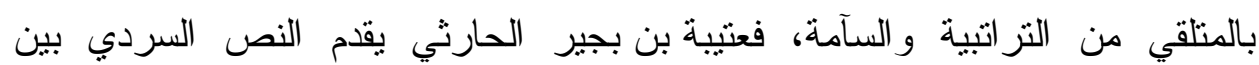

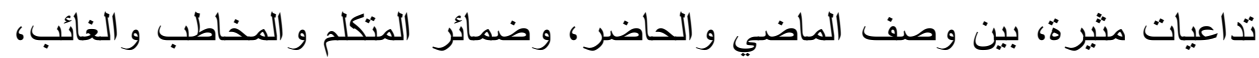
إذ يقف النص الشعري بطريقة لا تختلف عن طبيعة السرد المتعدد، وكما يقول(؟):

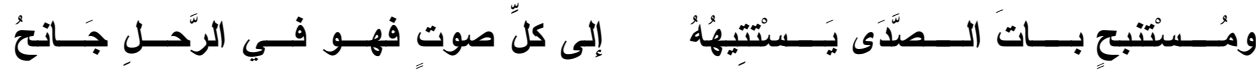

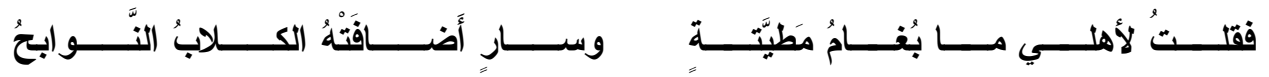

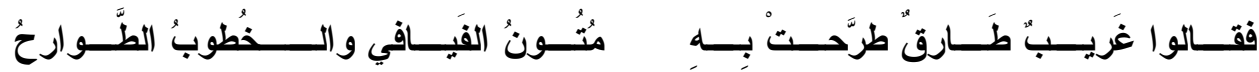

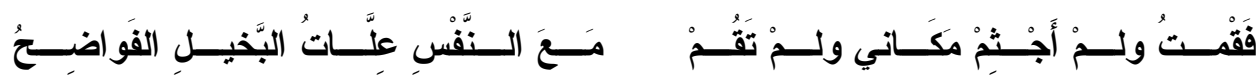




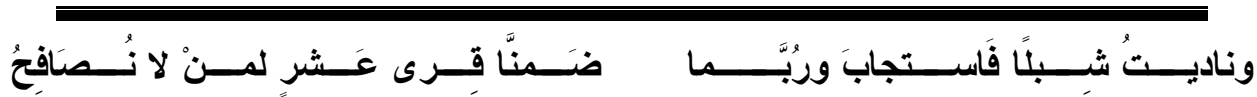

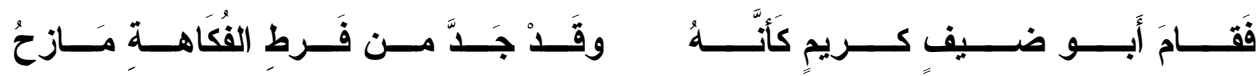

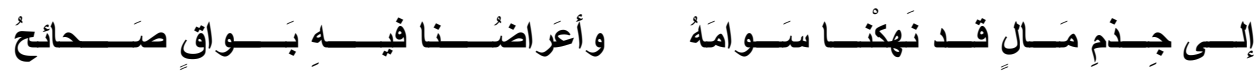

و على ضوء ذللك نجد الشعر اء استثروا علاقة الشخصية بالثاعر من خلال علاقة مزدوجة إما علاقة ذاتية الثاعر هو ذات الثخصية، و إما بطريقة غيرية إذ باء

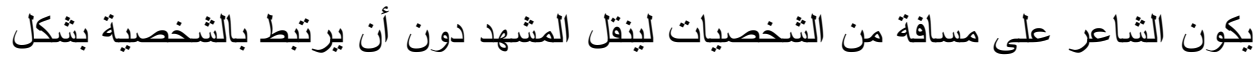

$$
\text { مباشر • بك }
$$

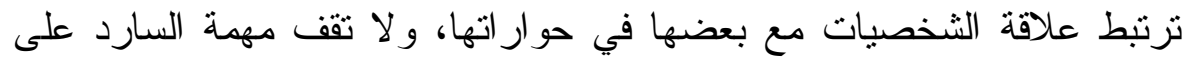
وصفها بل على الوقوف في ما يمكن أن تحتفظ به من أقوال وتصرفات، أو آراء

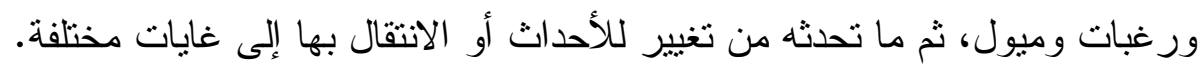

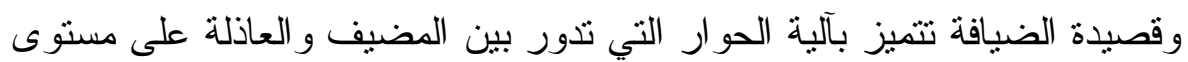

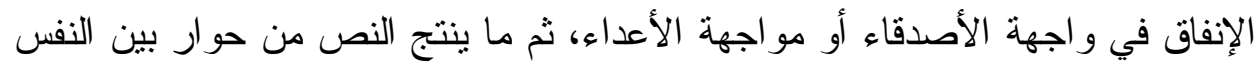

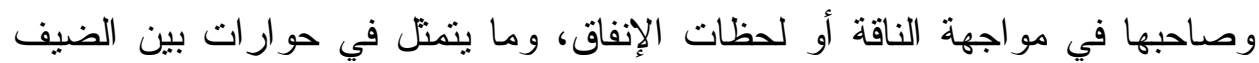
و المضيف. وصنا

وتتمتل تلك الحوارات بين حوارات داخلية أو ما يسمى في البناء القصصي

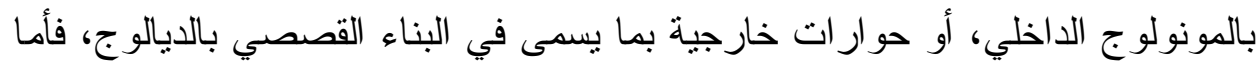

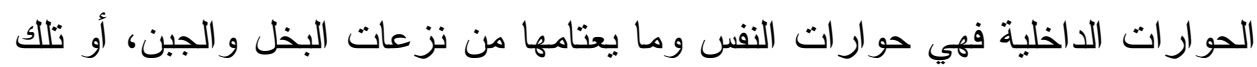

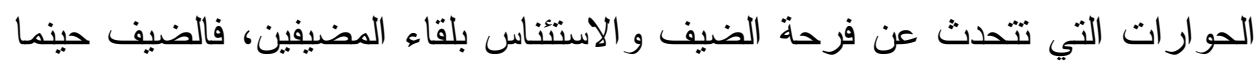
يلقى مضيفيه يخاطب نفسه المكلومة ويبشرها بفرحة الانتقال من الموت إلى الحياة، و هذا ما يمكن تلمسه في قول الر اعي النميري ('):

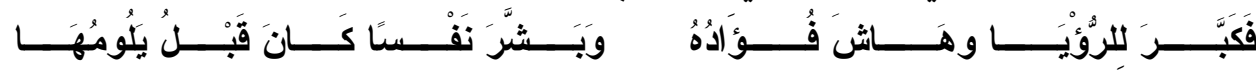

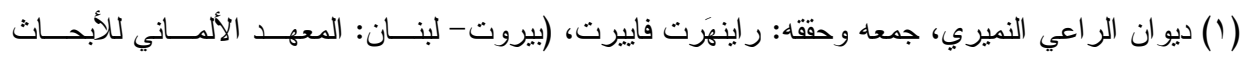

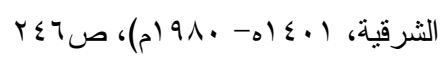


وقيمة الحوار في الفضاء الخارجي تأخذ مساحة واسعة من بناء القصبدة، فهي تتوزع بين عاذلة وبين ضيف وبين الثخصيات الثانوية المتعددة، ومن تلك الحوار ات ونيه بناء التي تتضح بشكل بارز، قصيدة الهذلول بن كعب العنبري في حواره مع زوجنه وندين عندما رأثه بطحن للأضياف (')

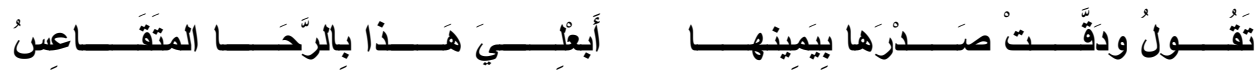

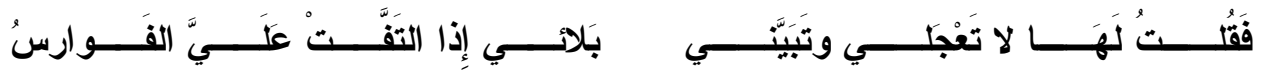
و الحوارات التي تأتي مع الثخصيات الثانوية فهي حوارات للأمر والامتثال لصوت المضيف، ويتضح ذلك في كثرة أفعال الأمر، ثم للمساعدة في القيام بقرى الضيف، ومن ذلك قول الأخطل حين يخاطب من يعطيه ناقة ابنه مالك لينحرها للضيف (r)

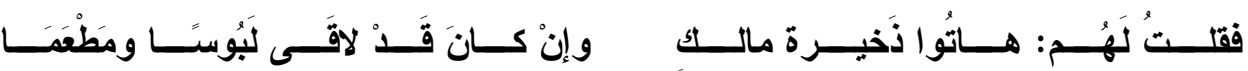
ويستمر الحوار بين الضيف و المضيف في بناء الشخصية ويحدث ذلك في لحظة

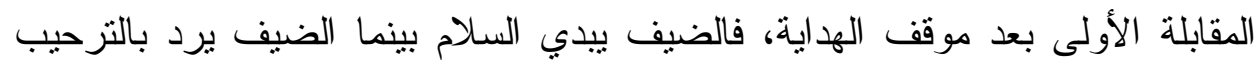
و التهليل، إلا أن الملاحظ أن صوت الحوار لا بيدو بشكل لافت في بناء القصيدة

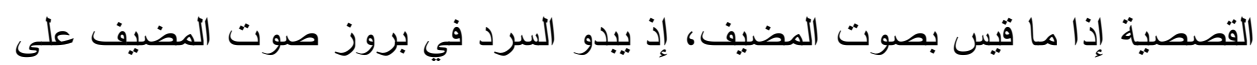

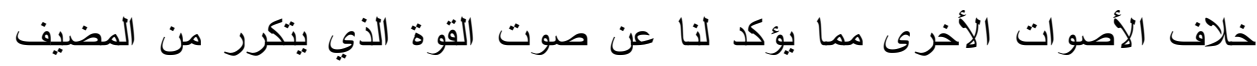
فيسيطر على مساحة من بناء القصيدة.

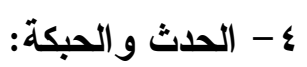

القصيدة لا تخلو من عدة أحداث "فنقطة الالتقاء المهمة في فن القصة" حدث بنشأ بالضرورة من موقف معين ويتطور بالضرورة إلى نقطة معينة يكتمل عندها معنى عنى

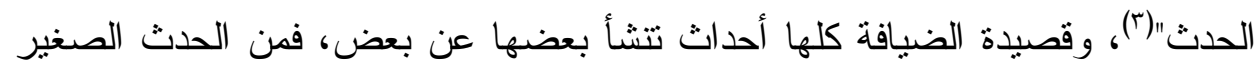

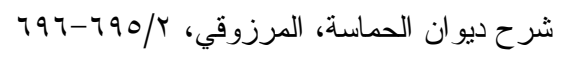
- لم أجد له ترجمة.

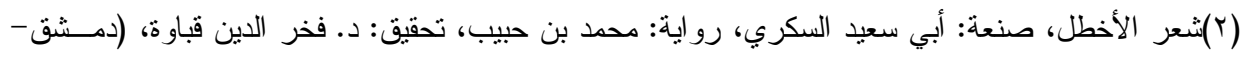

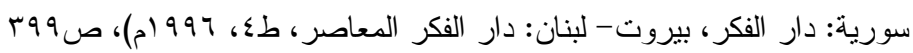

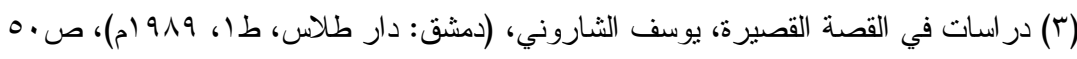


ينشأ الحدث تلو الحدث، وبالتالي يصبح كل حدث مثير للاهنمام، فمهمة الراوي " ليست

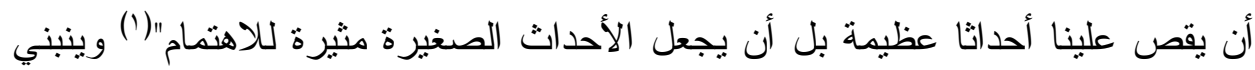
على إثرها تسلسل الأحداث المتتابعة.

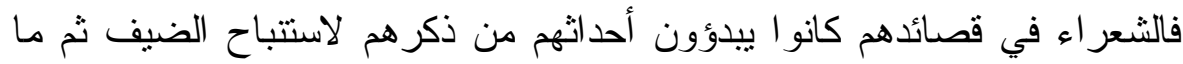

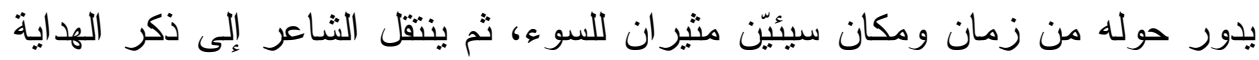
بالنار والكلاب، وحماسة المضيف لذلك، ثم يذكر ما يحدث من من حسن للاستقبال و الملاطفة، وما يعقبها من أحداث الإبل المنحورة وحدث الجفان و القدور، ومن ثم تقديم

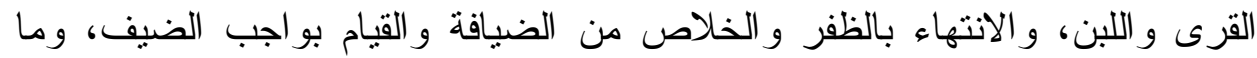

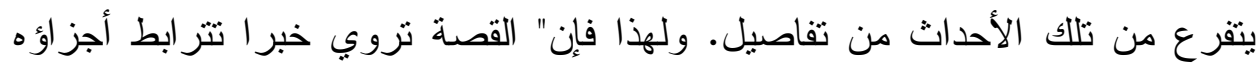
وتفاصيله نز ابطًا عضويًا يؤدي كل منها للآخر بالضرورة و والحتمية ليحدث أثزًا كليًا،

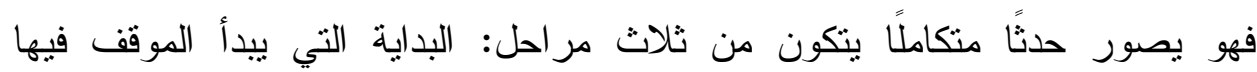
بالتبلور، و الوسط وفيه ينمو الحدث، وتتشابك عناصره، و النهاية التي يكتمل فيها معنى دئل

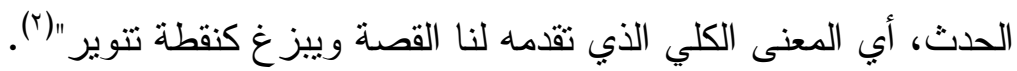

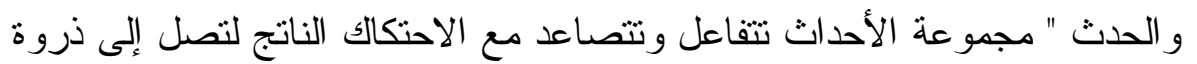
التعقيد، فالحدث يشمل أفعال الشخصيات وصر اعها و الوقائع المتو الية إذ هي التي تولد التاعل

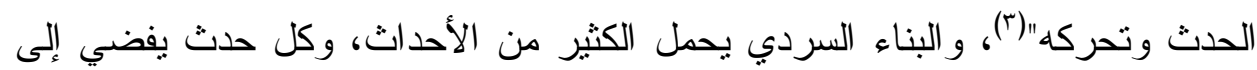

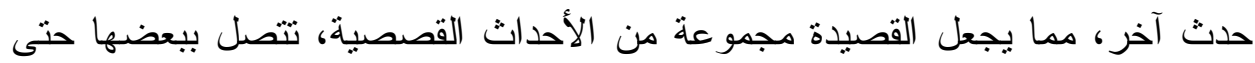

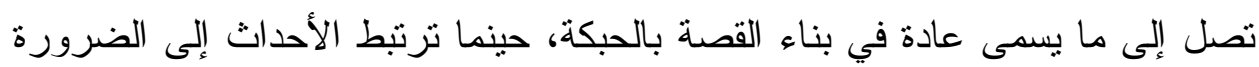
و البحث عن الخلاص ينتج الثـاعر عن مخرج يخرج الأزمة الحادثة عن مخرجها.

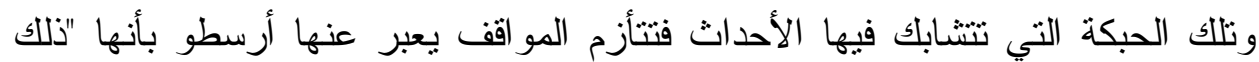

(1) بنية الخطاب السردي في القصة القصيرة، ص19.9

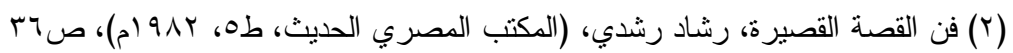

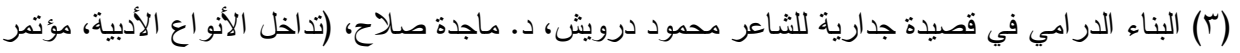

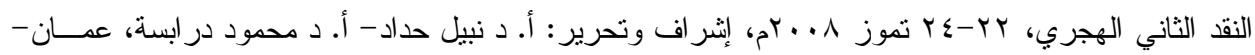

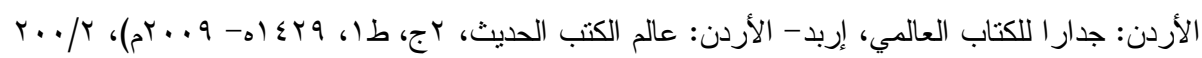


القسم من المأساة الذي يبدأ ببدايتها، ويستمر حتى الجزء الأخير الذي يصدر منه

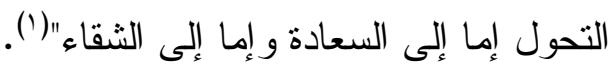
وسرد الأحداث هو تتابعها في السرد أما الحبكة فهي وصول الأحداث إلى مفترق طرق تتأتى إلى البحث عن موقف للخلاص، فإذا قدم الضيف ثم تم استقباله وقر اه فهذا يعني سردا للحدث، وإذا قلنا قدم الضيف ولم نجد له قرى ثم أخذنا طعام الأطفال و أهل البيت وقربناه الضيف فهنا نعني بالحبكة للأحداث، وبالتالي فإن وقوفنا أمام حدث كهذا

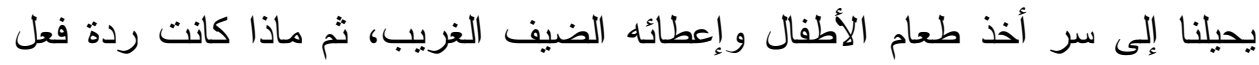
الضيف بعد هذا. إننا أمام أسر ار غائبة تحيلنا إلى قر اءات أكثر تفكير ا.

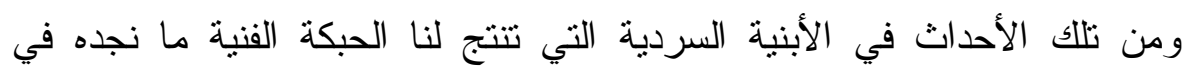
قصيدة الحطيئة التي يلقانا فيها وقد هم بذبح ابنه وتقديمه إلى الضيف نظرًا لخلو البيت

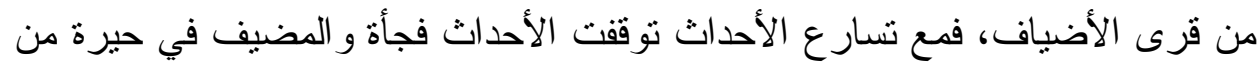

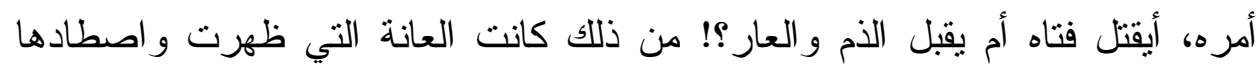
مرحلة المنفذ الذي شق طريق الأحداث نحو الخلاص بعد أن كانت الأحداث في مرحلة

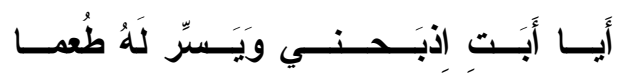

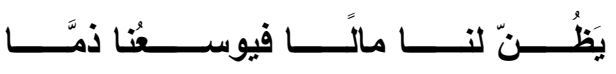

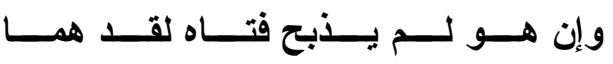

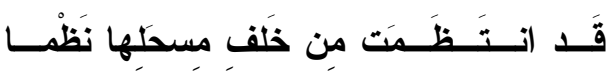

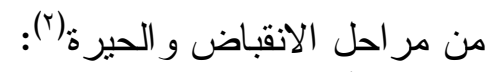

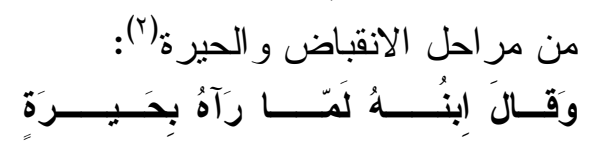

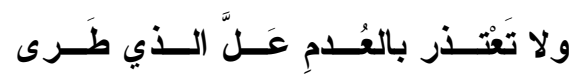

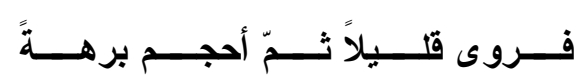

ودائمًا ما تكون الحبكة في بناء الضيافة حينما تتشابه الأحوال بين الضيف و المضيف فلا يقر المضيف على تلبية طلبات الضيف، مما يحدو بالمضيف أن يتخذ

(1) فن الثعر ، أرسطو طاليس، ترجمة وتحقيق: عبد الرحمن بدوي، (بيروت: دار الثقافــة، ط. د، بVو ام)، ص. (r) ديوان الحطيئة، رواية وشر ح: ابن السكيت، در اسة وتبويب: د. مفيد محمد قميحة، (بيروت- لبنـان: دار

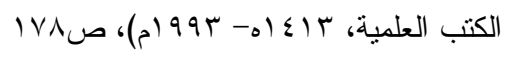


سبلًا طريفة تخرجه من عمق الأزمة التي تمرّ به، كما كانت البوابة التي أخرجت المضيف في قصيدة الحطيئة. ولهذا فإن وجود الأحداث في البناء يبعث النص إلى التماسك، فـ" السرد بوصفه

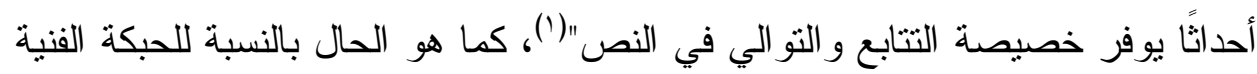
التي تمنح النص "التماسك و البناء المتسق، و الانتخاب، و السببية، و الاطر اد، و والتنتويق،

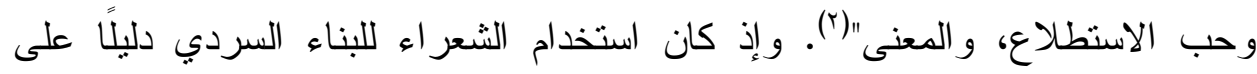
اتخاذهم تلك النمطية التي تشعر المتلقي بشيء من الكتلة الواحدة والوحدة الثشعورية

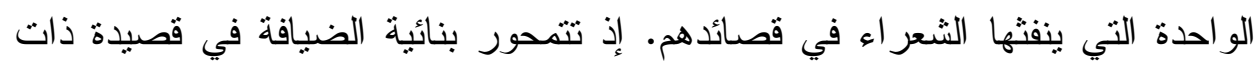

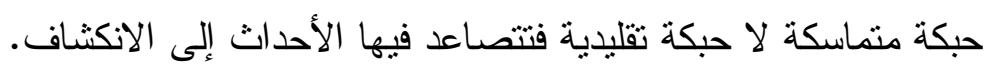

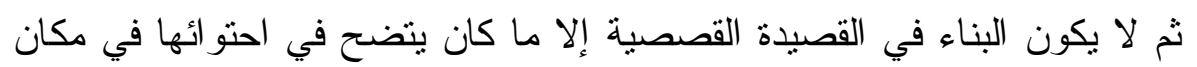
يتمثل في اليفاع وعلى مسر ح من الصحر اء، وعلى اتساع يجمع الأضياف فلا يضيق،

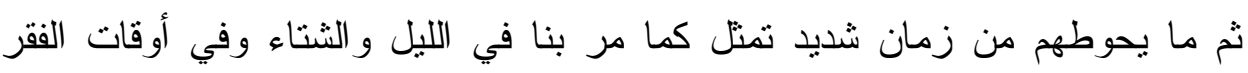

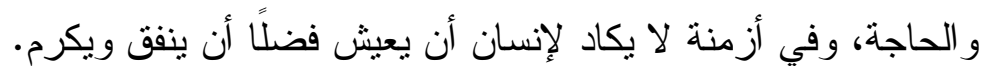


المبحث الثاني: الزمن السردي.

استخدم الثعر اء في القصيدة القصصية تقنيات سردية منحت القصيدة جانبًا من جو انب الوعي بآليات السرد الحديث، ومن تلك التقنيات عنايتهم بعنصر الزمن المتمثلة

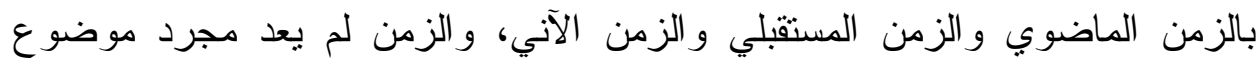

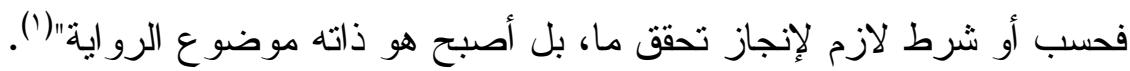

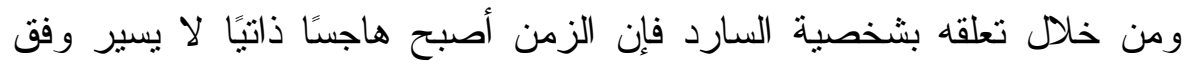

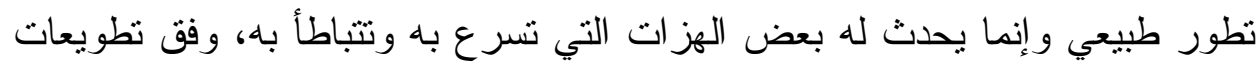

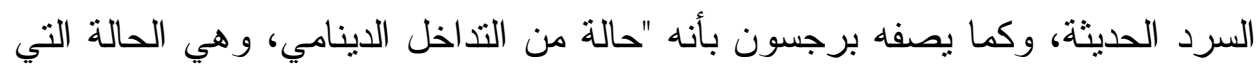

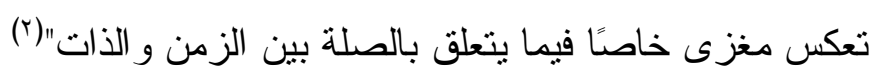

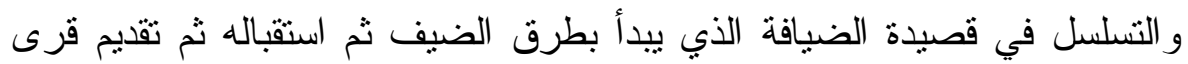

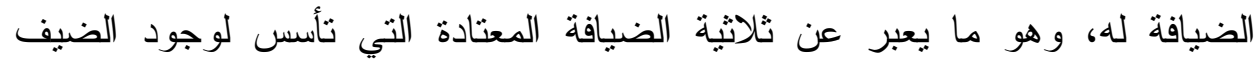
و المضيف و الأداء المشترك بينهما، ثم تدخل الضيافة في التفاصيل من خلال استخدام

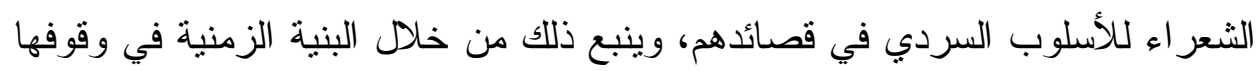

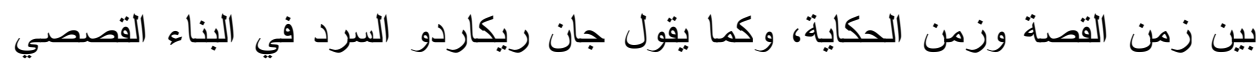

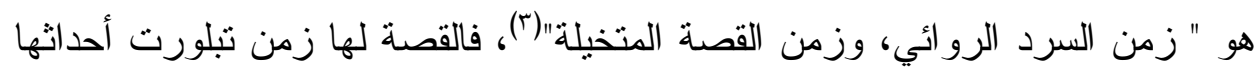

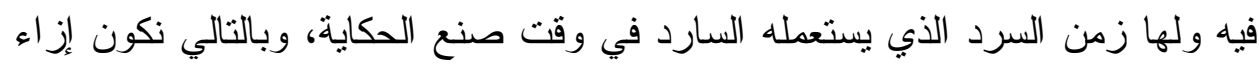

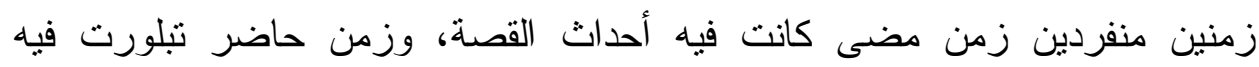

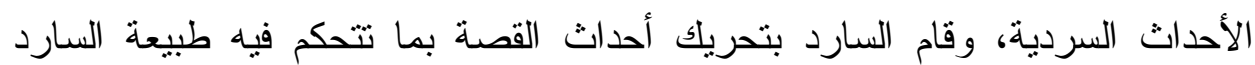

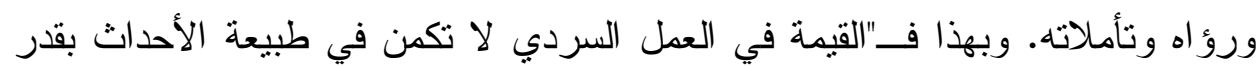

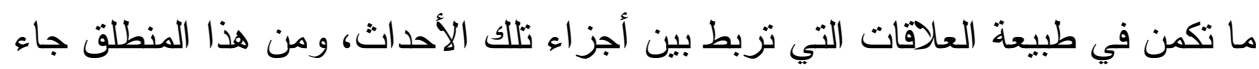
تمييز هم بين زمن الحكاية وزمن السرد"(£).

(1) عالم الرواية، رو لان بورنوف- ريال اوئيليه، ترجمة: نهاد التكرلي، مر اجعة: فــؤاد التكر لــي - محسـسن

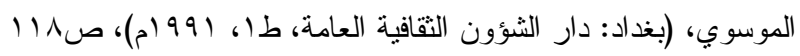

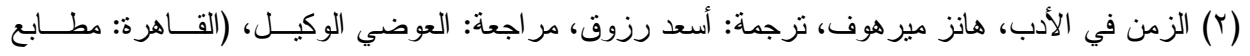

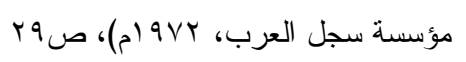

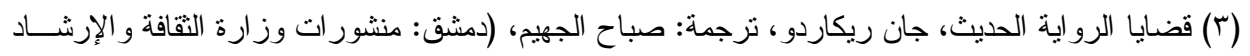

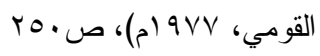

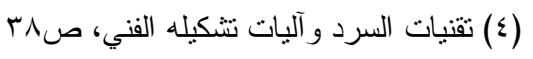


إن محاولة الشعراء تكريس الأحداث في البناء القصصي ليس الهقصود منه أن أن الناء

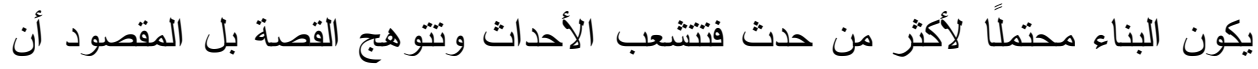
يكون هناك رباط بين أحداثها فتتعلق الأحداث بينها. ولهذا كان هناك الكات اهتمام بأزمنة الأحداث في زمن السرد.

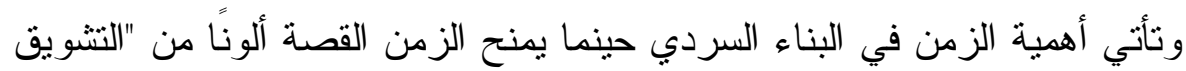

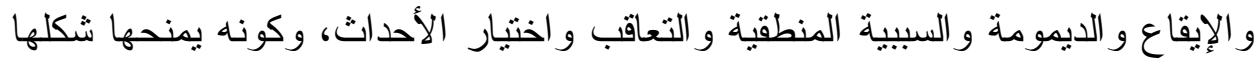

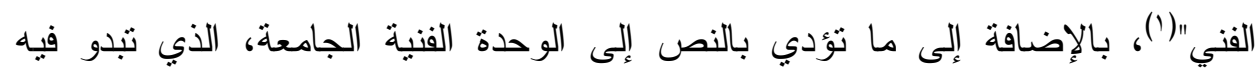

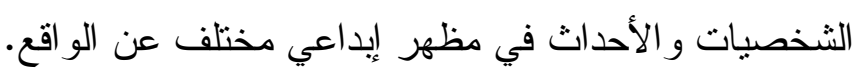

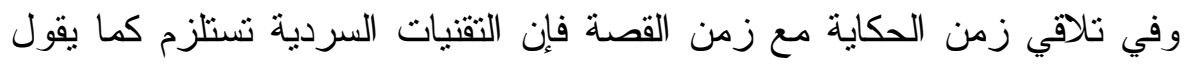

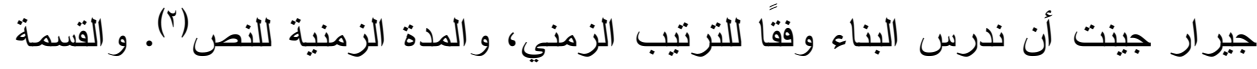

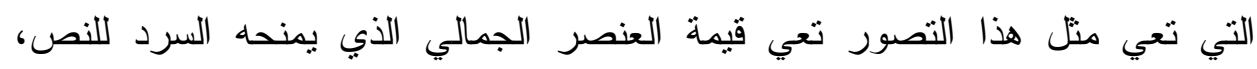

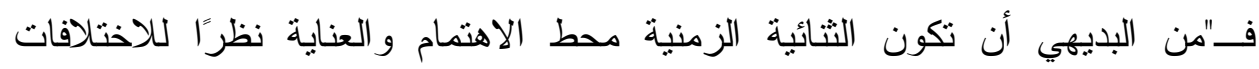

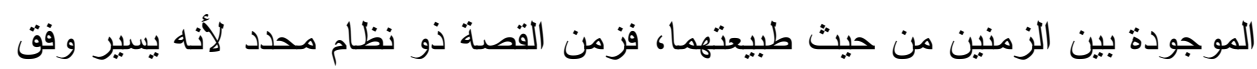

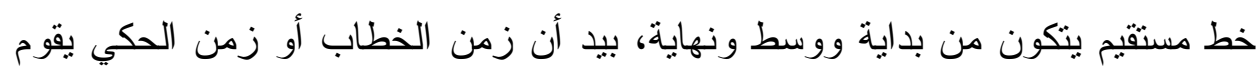

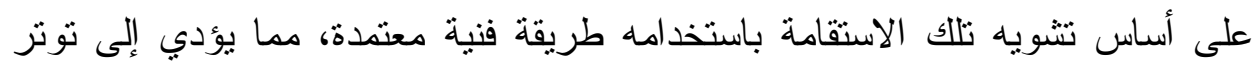

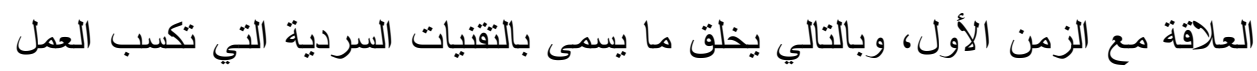

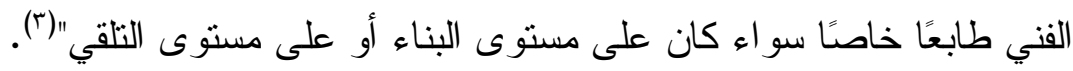

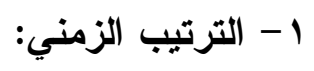

أظهر الثعر اء في بناء القصيدة السردية جزءًا من التزتيب الزمني يختلف عن

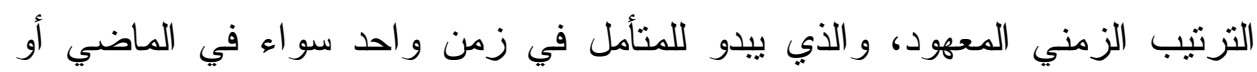

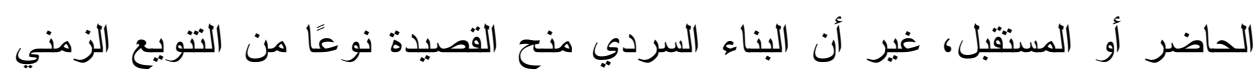

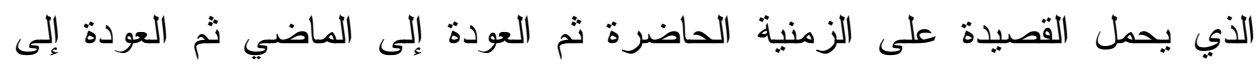

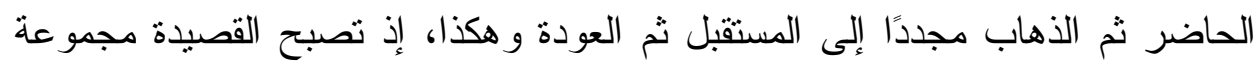

( (1) ينظر : بناء الرواية- در اسة مقارنة في ثلاثية نجيب محفوظ، سيز ا قاسم، (القاهرة: الهيئة المصرية العامة

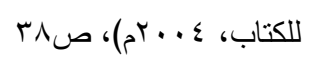

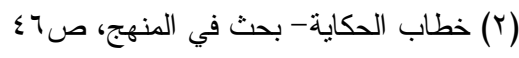

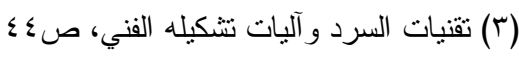


من الأزمنة المتجددة، كلما بدأ زمن اختفى الآخر وكلما عاد الزمن اختفى الآخر، وهذا"

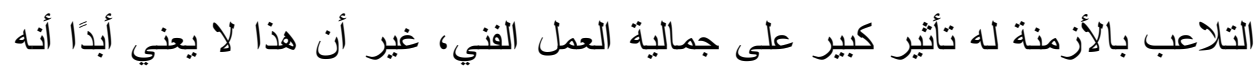

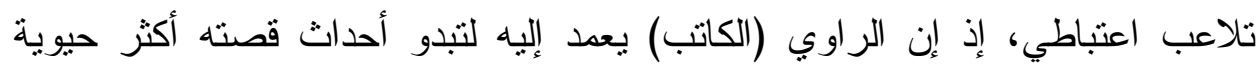
وجودة في نظر القارئ، وليحقق غايات فنية أخرى كالتشويق وإبعاد الملل والإيهام

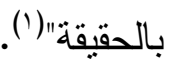

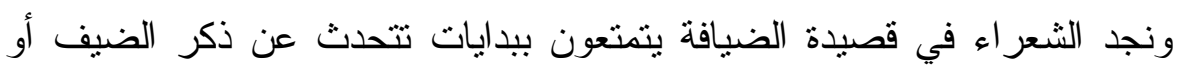

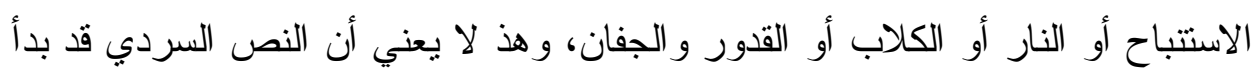

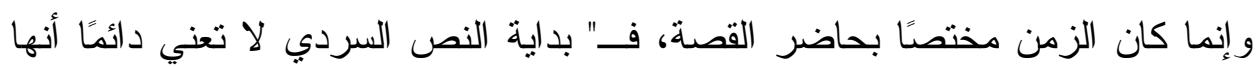

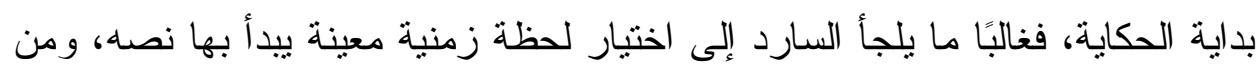
هذه اللحظة يتحدد حاضر القصة الذي يعد المستوى الأصلي لها"(؟). وذلك أن اختيار

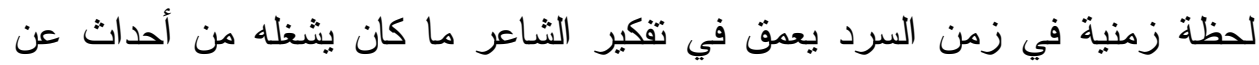

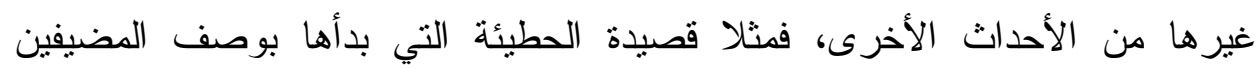
وحالهم البائس يشير إلى ما كان يشغله من سوء حال العائلة المضيفة التي لم تعد قادرة

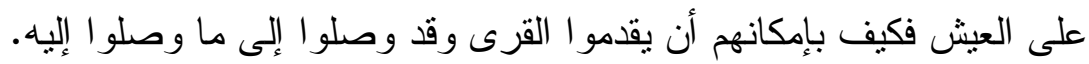

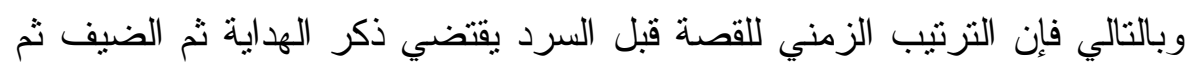

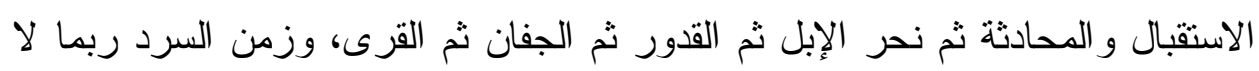

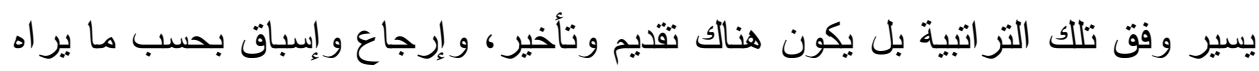

$$
\text { ألثاعر في نصه السردي. }
$$

الاسترجاع من التقنيات السردية التي تحاكي الترتيب الزمني في القصة، ومن أهم

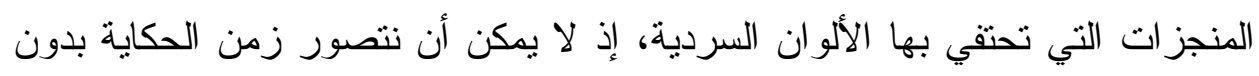

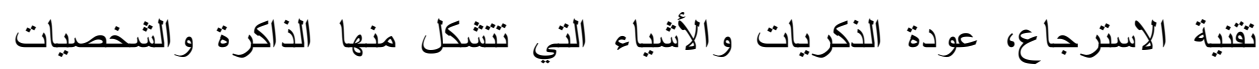
و الأحداث، و الاسترجاع يستخدمه الثعر اء من أجل إضاءة القصيدة بشيء من المعالم 
التي تخفى أثناء السرد، وكما "يلجأ إليه الكاتب لملئ فر اغات زمنية تساعد على فهم

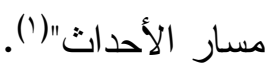

ويتمنل الاسترجاع في البناء السردي لقصيدة الضيافة في ذكر معلمٍ من ناريخ الثخصية، أو صفة تخفى عن المتلقي، وبالتالي يأتي الشاعر لذكرها هاءو التتبيه عليها،

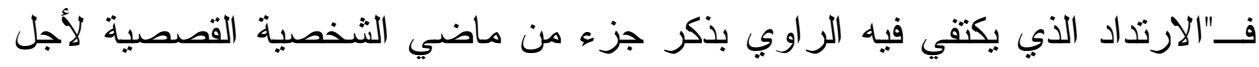
أن يتعرف القارئ على بعض خصائص تجاربها الحياتية"(؟).

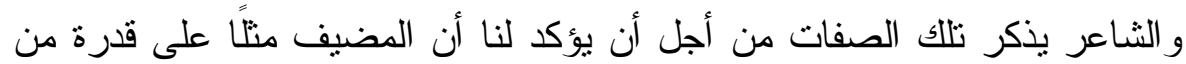

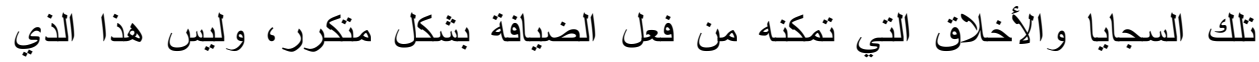

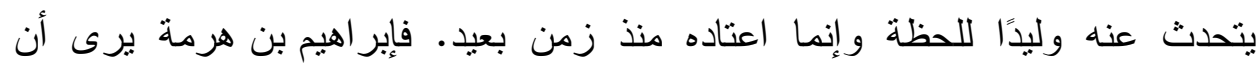

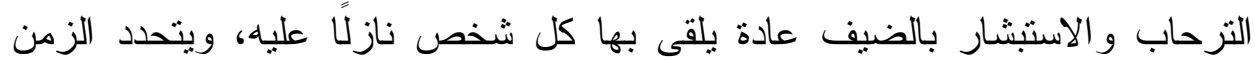
الاسترجاعي في المعنى المضمر الذي نستوحيه من ذللك الاعتياد لكل عائد يأتيه

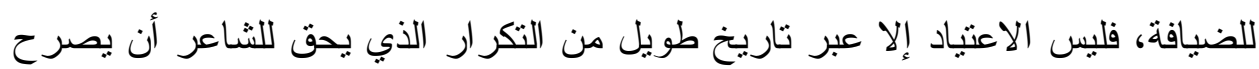

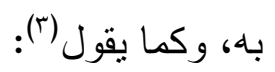

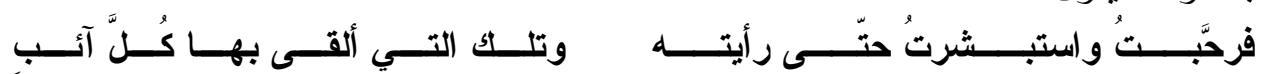
و استعمال الثعر اء لاسم الإشارة يبدو كثيرًا في أساليبهم السردية وذلك بإثـارتهم إلى الزمن الماضي، وكما يتحقق ذلك في وصاية المضيف لمن سبقه من أولئك الذي لئي

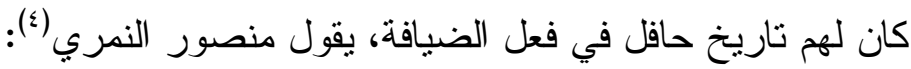

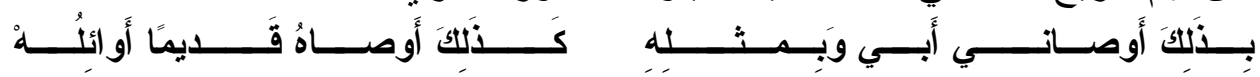

$$
\begin{aligned}
& \text { ( () بناء الرو اية- در اسة مقارنة في ثلاثية نجيب محفوظ، صهاه }
\end{aligned}
$$

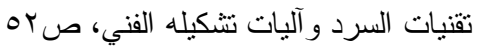

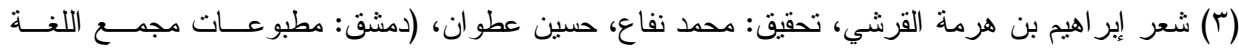

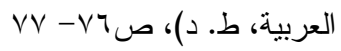

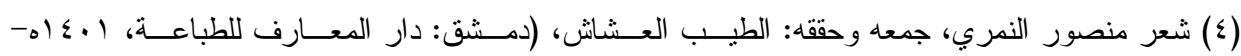

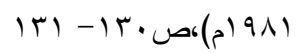

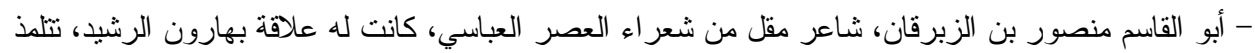

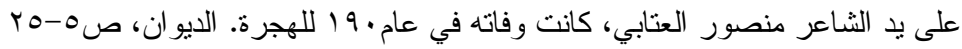


ويصرح الشعر اء بالعودة إلى الزمن الماضي في ذكرهم لشيء كان من أجود ما

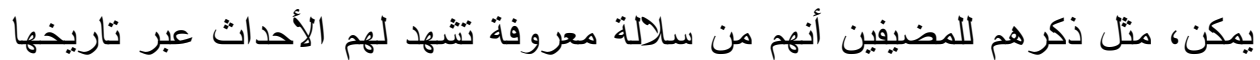

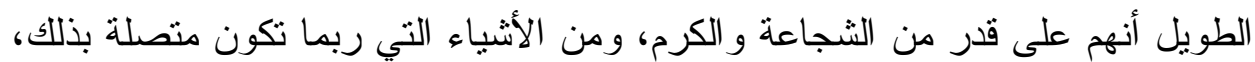
قول منصور النمري في وصف شخصية الناقة وكيف أنها من سلالة كريمة ومن فحل له مواصفات نفيسة وليس الناقة التي قدمت للقرى إلا من أجود الإبل، وتتمحور تقنية الاسترجاع في ذكر الثـاعر للفعل (كان) ('):

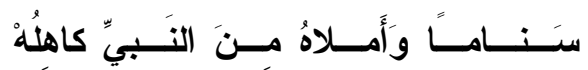

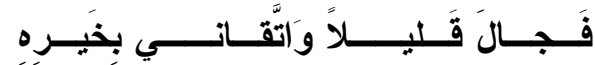

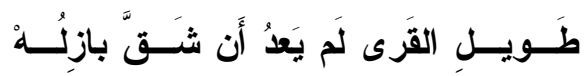

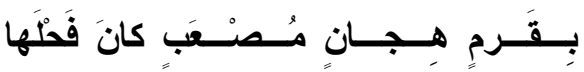
وتتمثل تقنية الاسترجاع في ذكر الشعر اء كلمات منل الزمان، أو الأمس، أو الماضي، وما يشتق منها في تصريح لكلمة تدل على الزمن الماضي، ومما يبدو لنا

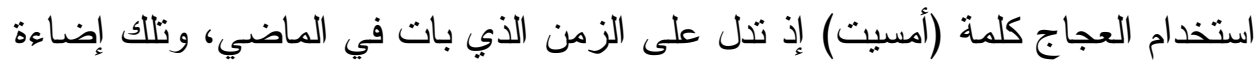
تشعر أن الضيف الذئب كان على حال ويحاول أن يتغير هذا الحال إلى زمن لا يثابهه

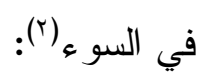

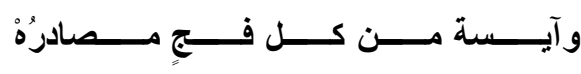

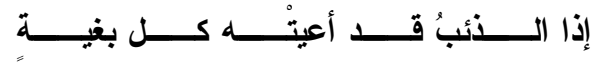

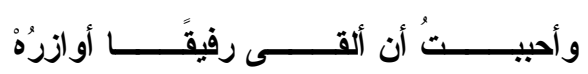

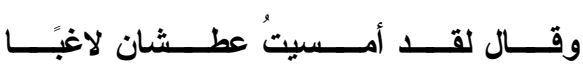
وبناء على ذلك كانت تقنية الاسترجاع تقنية مستخدمة في النصوص الثنعرية، و استخدامها أضفى جانبًا مهمًا في التشويق وكسر الجمود ثم ألمح للمتلقي تاريخًا غائبًا في زمن القصة المتحدث عنها.

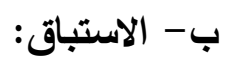

الاستباق تقنية التوقع التي يتحدث الثعر اء عن أثنياء في النص وتلاك الأشياء لهــا

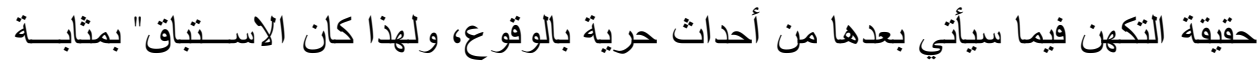

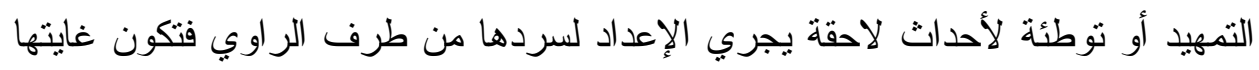

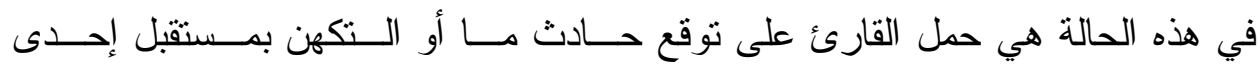

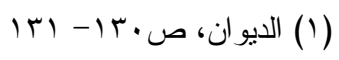

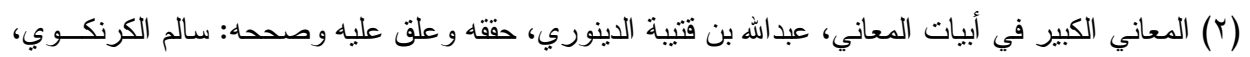

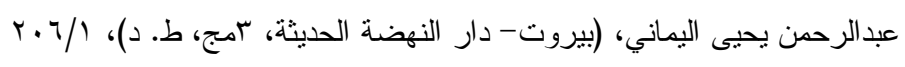




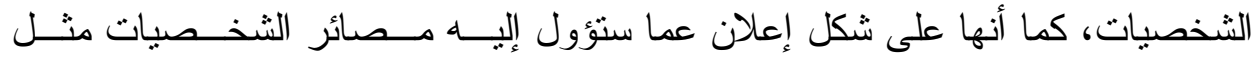

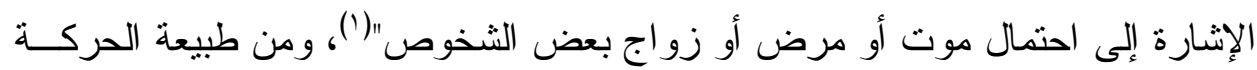

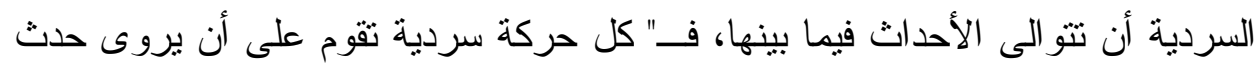

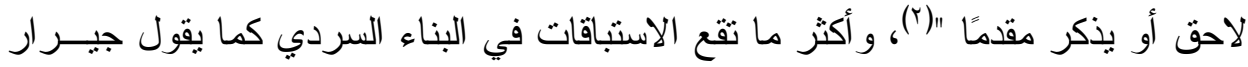

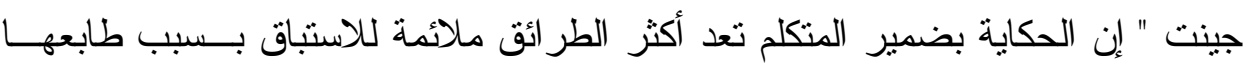

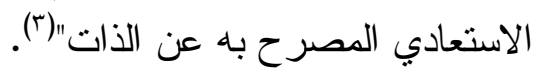

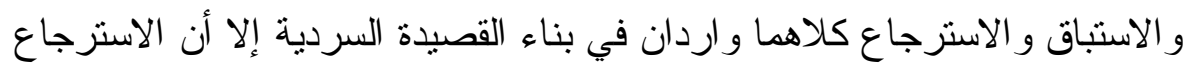

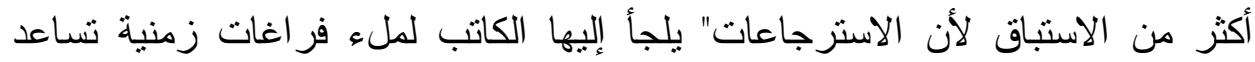

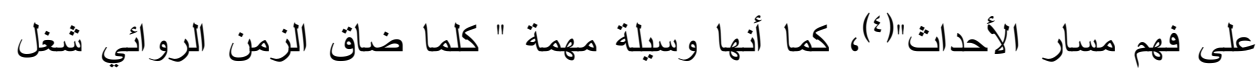

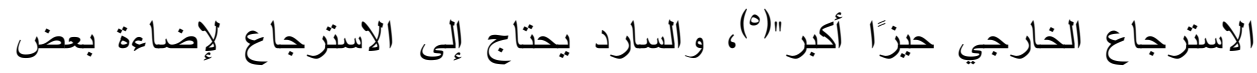

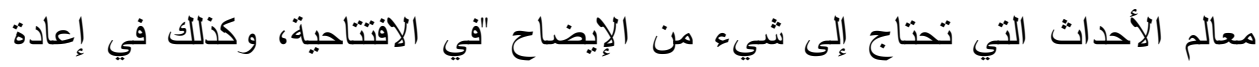

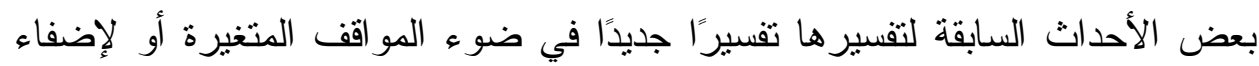

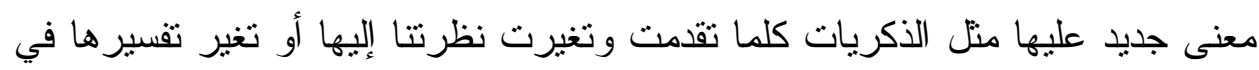

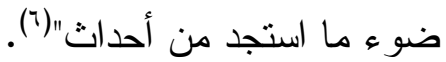

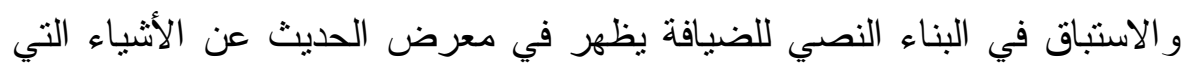

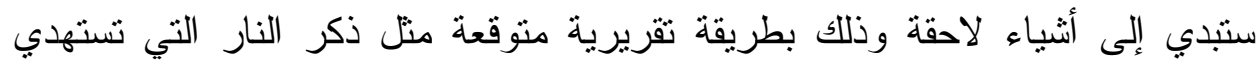

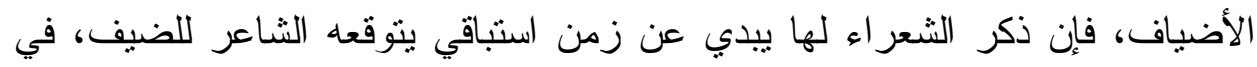

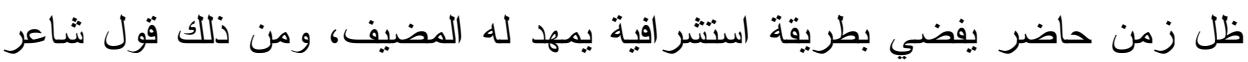
الحماسة) (vن)

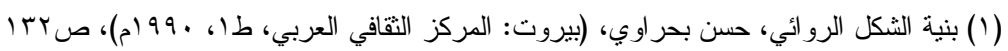

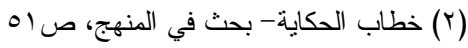

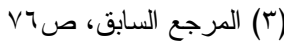

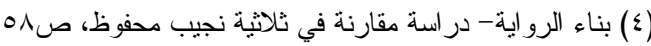

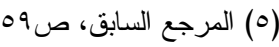

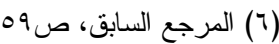

(V) شرح ديو ان الحماسة، الخطيب التبريزي، تحقيق: محمد محي الدين عبدالحميد، (القاهرة: مطبعة حجازي، عج، ط.د)، 


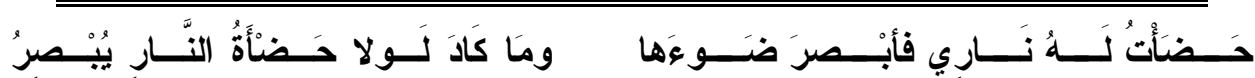

إن التقييد الذي أفصح عنه الثاعر بقوله (وما كاد لولا) عملية تقرر استباقية

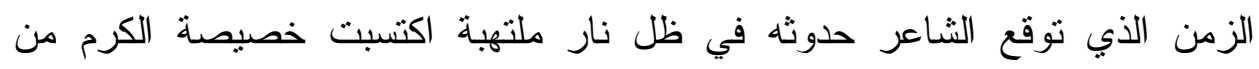
صاحبها. كما هو الحال في ذكر الثعر اء إلى بشاثة الاستقبال و الابتهاج و الاستئناس

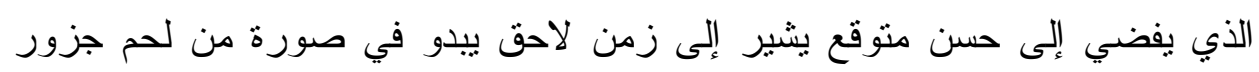
ولبن ومبيت.

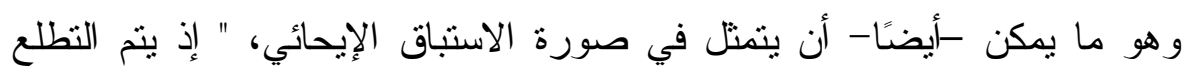

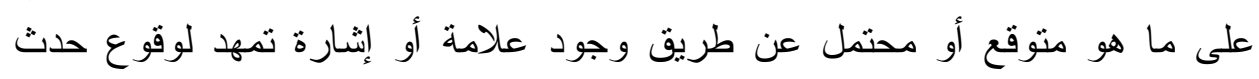

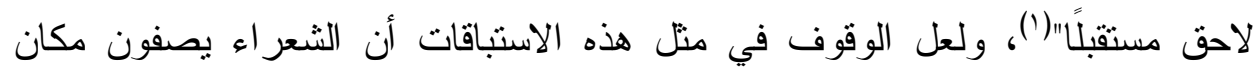

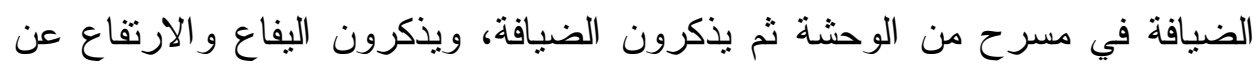

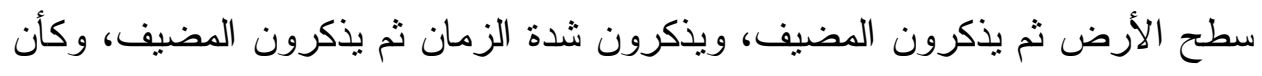

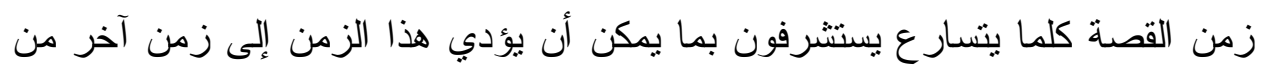

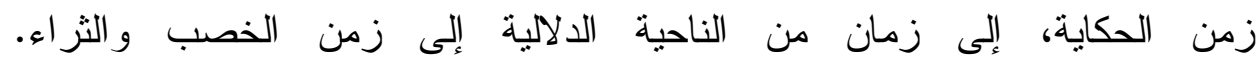

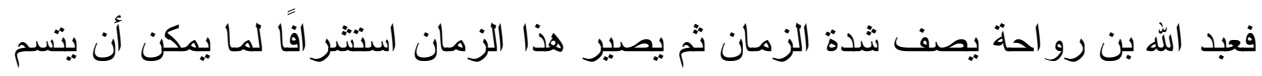

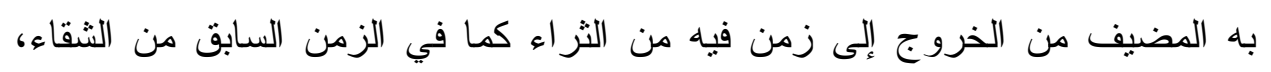

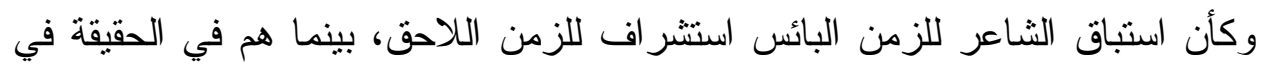

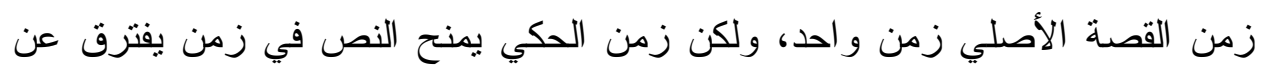

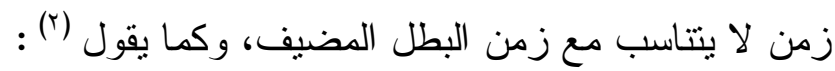

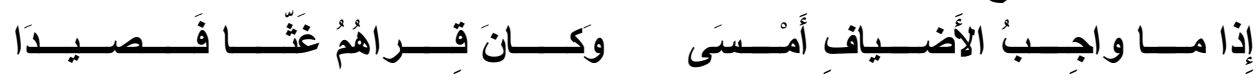

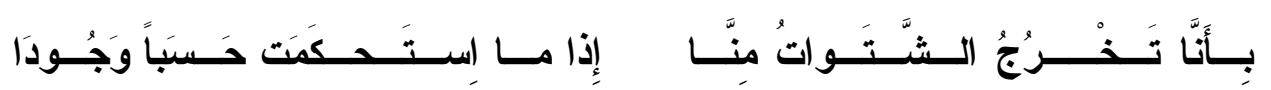

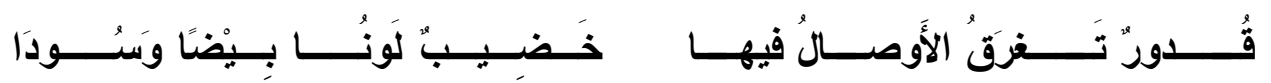


وبناء على ذلك تبدو تقنية الاسترجاع و الاستباق تقنيات سردية مستوعبة في بناء قصيدة الضيافة، واستخدمها يشد النص الثعري إلى النص السردي، مما يضمن الثراء النصي و الكثف عن أثياء خارجة سياق النص الزمني للقصة.

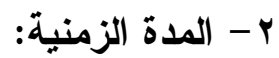

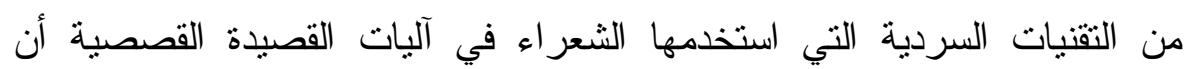

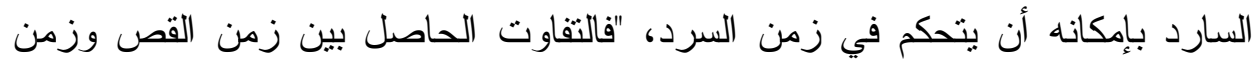

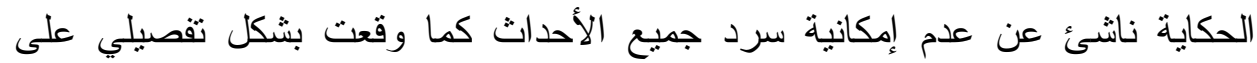
مستوى الصياغة الخطية، وإن ما يستخدمه الر اوي أو السارد من آليات ووسائل تقنية،

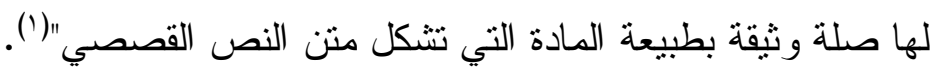
و المدة الزمنية بين حدث وحدث تقتضي أن يكون السارد على وعي بطريقة إبطاء السرعة الزمنية وتعجيلها، وكما تقول يمنى العيد" الراوي يتخير السياق المناسب ليمدد

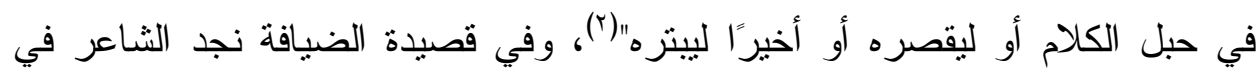
ظل المشهد السردي يحاول أن يسرّع من حركة الزمن نظرًا لما تقتضيه سياقات

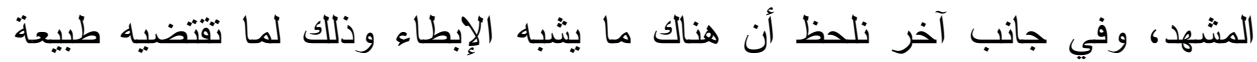

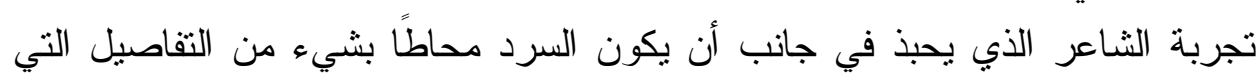
تمنح النص إضاءة عن باقي السياقات الأخرى. أ- تسريع السرد:

تعتمد تقنية تسريع السرد إلى اتخاذ اللمحات الخاطفة التي يتحول معها الزمن من

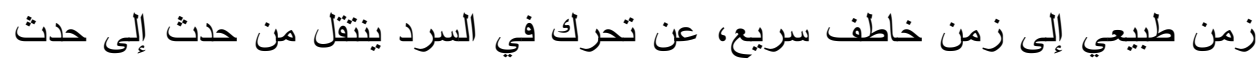
بما يشكل القفزة التصويرية، وتتضح آلية تسريع السرد من خلال تقنية الحذف، وتقنية التلخيص.

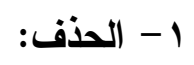

يكثف الثعر اء عن تقنية الحذف باعتبارها وسيلة تمكنهم من تجاوز ذكر

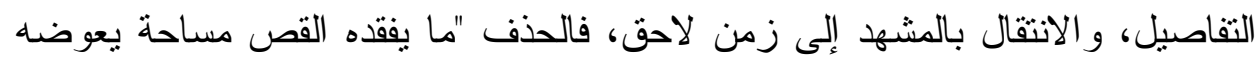

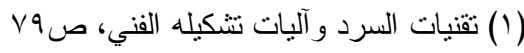
(r) تقنيات السرد الروائي في ضوء المنهج البنيوي، د. يمنى العيد، (بيــروت: دار الفــار ابي، طا، ـ99 (1))، 
كثافةً ووقعًا، فالتسريع يقرب المفاصل المشحونة ويكسبها عمقاً وكثافةً تخييليةً، وفوق

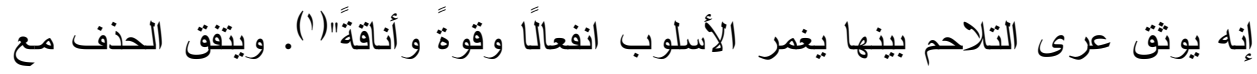

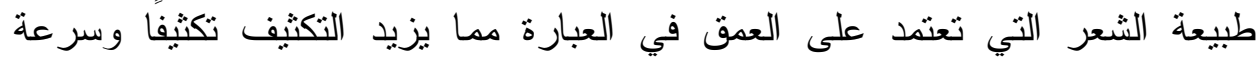

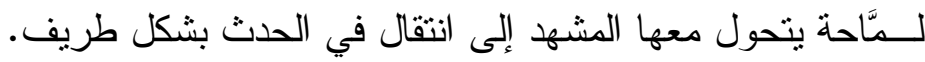
ومما نقف عليه في آلية الحذف في قصيدة الضيافة أن الشعر اء يصفون الحذف فئفي بطريقة مضمرة، وللحذف لديهم معان مهمة تستبطنها الألفاظ في جوفها إثـارة إلى ذلك فئل الزمن المحذوف، من خلال اهتمام كل شاعر بنقل القصة بكيفية معينة. وزمن الحذف ونف

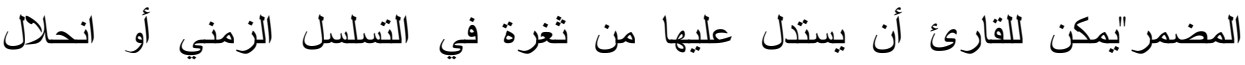

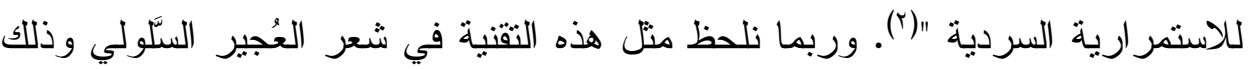

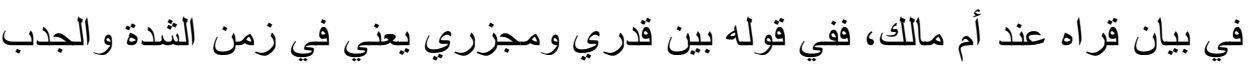

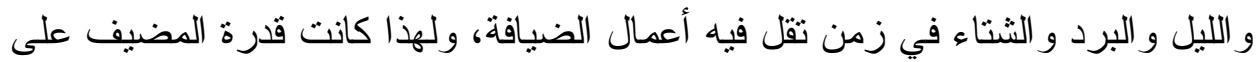

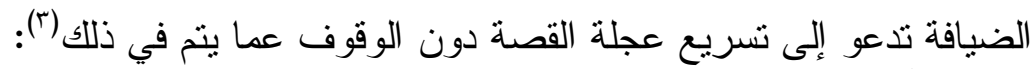

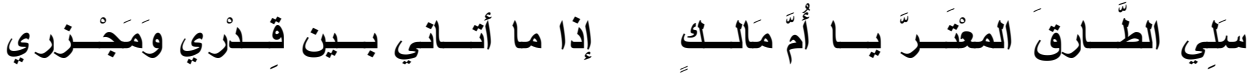

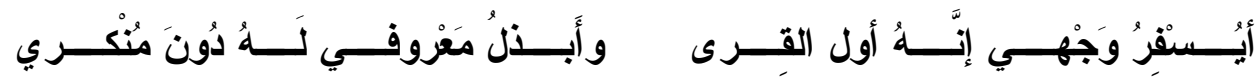

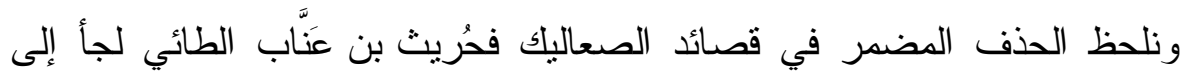
حذف المدة الزمنية و الفعل الذي سيكون إجابة للعواء الصادر من الضيف ثم ما يقابل

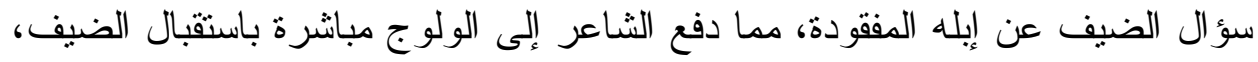

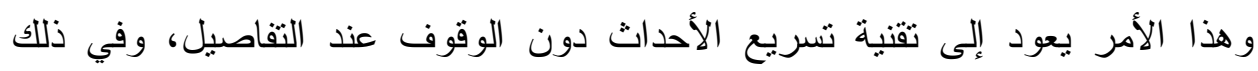

يقول (£)

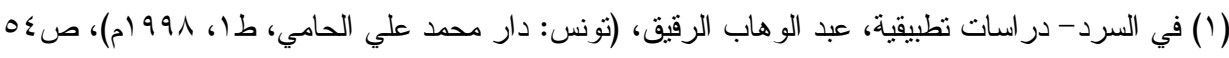

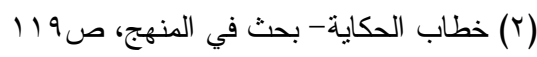

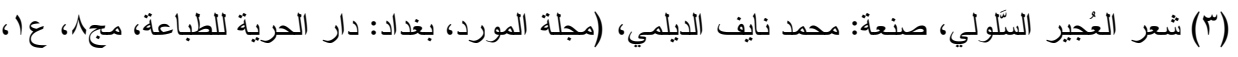

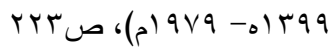

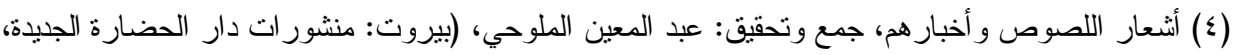

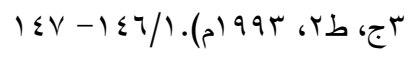

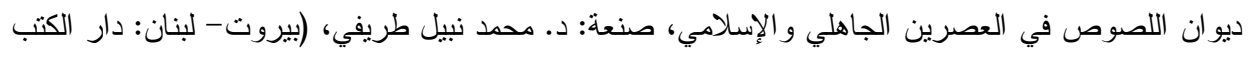

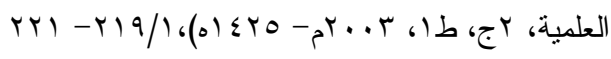




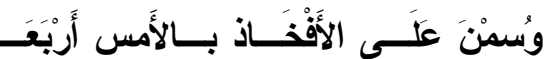

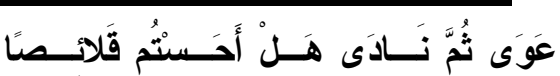

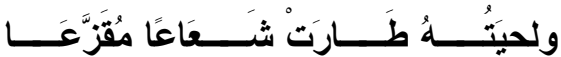

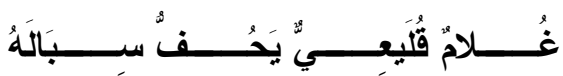

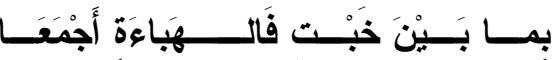

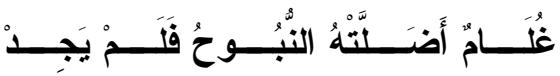

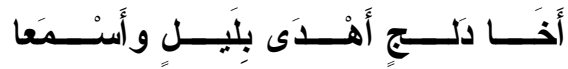

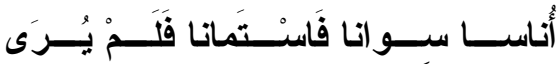

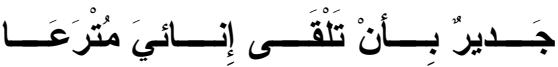

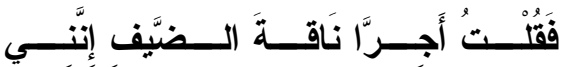
و على ضوء ذلك نجد تقنية الحذف مناسبة جدًا لطبيعة القصة الثعرية، فالثعر أساسًا ينحاز إلى التكثيف، و استخدام منل هذه التقنية يمنح النصح بعدًا تكثيفيًا أكثر من فن فئه

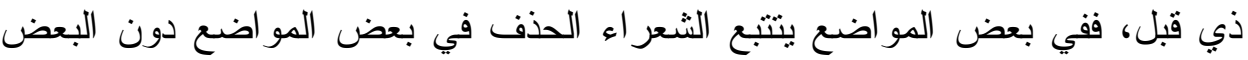

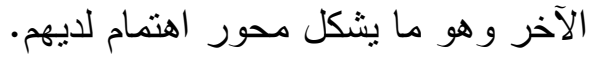

$$
\text { r - r التخيص: }
$$

هي الثقنية التي يريد منها الثاعر أن يسير على وصف أحداث متفرقة وقد تبدو

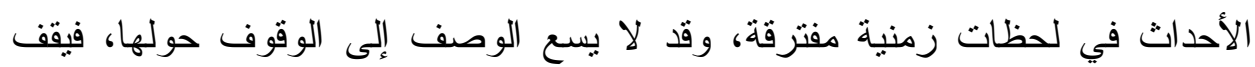

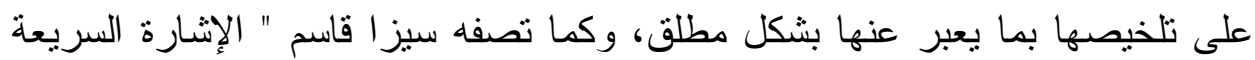

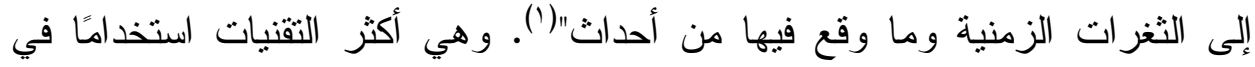
سردية الثعر اء، وهي تعني تكريس ما يجمعه المضيف في قصص متفرقة، فيبدأ الثاعر في ذكر ما قدمه في مجال الضيافة، فالمدة الزمنية التي تستغرق اتساعات

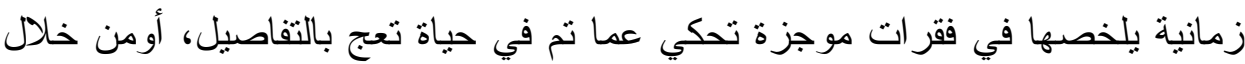

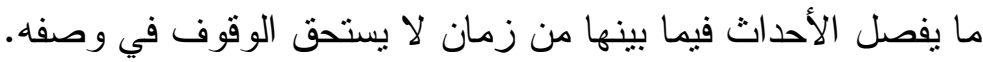

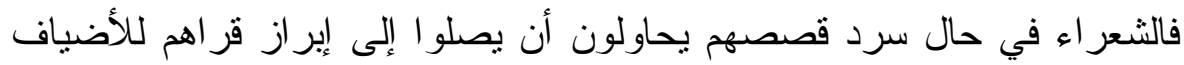

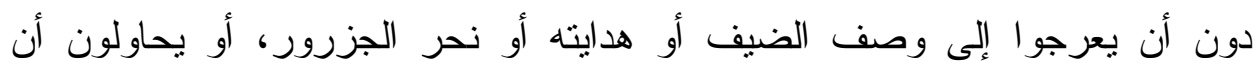
يقتطعوا من تلك الأحداث المتفرقة بعضًا من الوصوف التي وني تشير إلى ذلك الحدث،

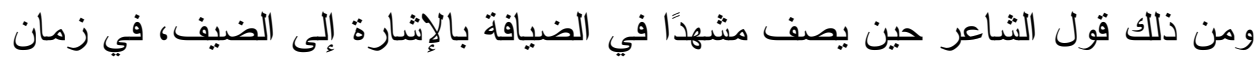


الليل و الثتاء و السنة الممحلة، وفي وصف المضيف حين يلقاه بالبشر و المضاحكة

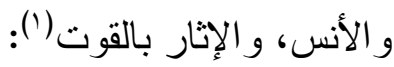

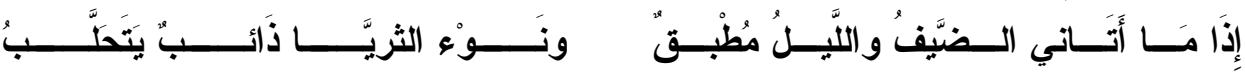

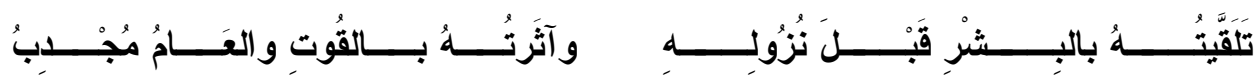
و آلية التلخيص تتاسب إلى حد بعيد البنية النصية لدى الثعر اء الصعاليك، فالشعر اء الصعاليك لا يحبذون وصف كرمهم بشكل دقيق كما يبدو عند الشعراء

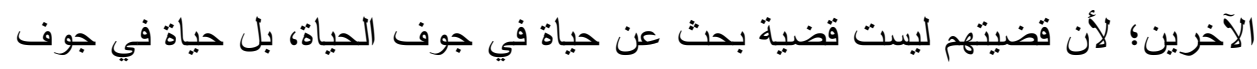

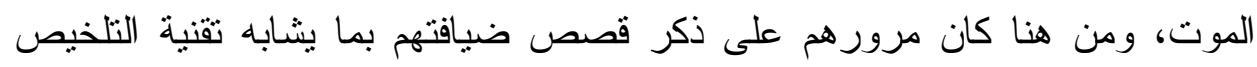

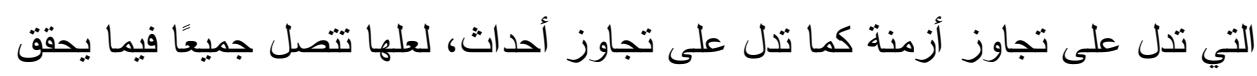

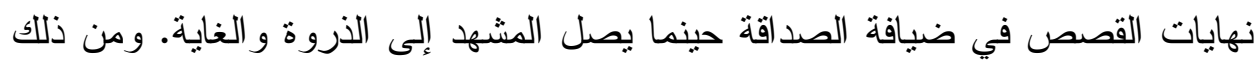

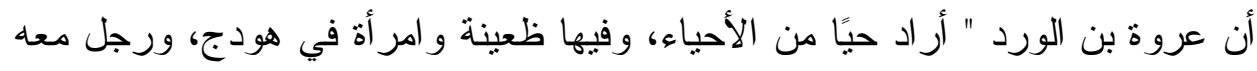

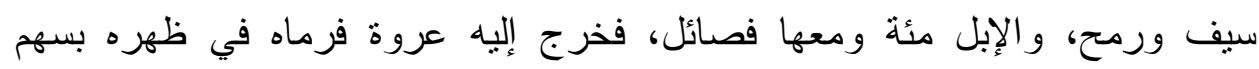

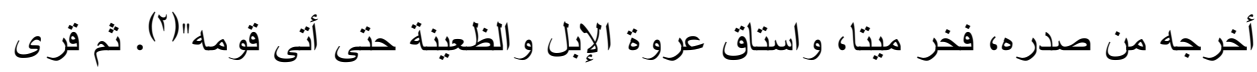
الصعاليك من الإبل، ومن ذلك قوله (َ):

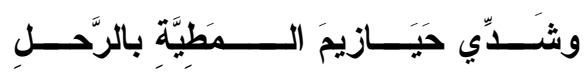

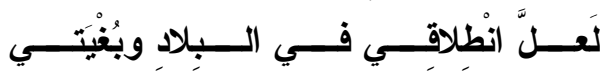

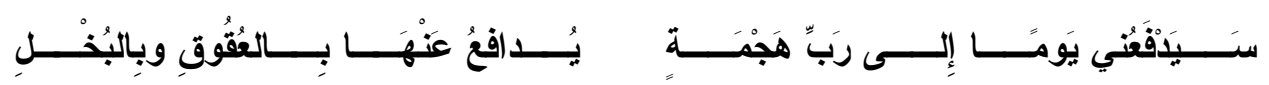
و المتأمل برى أن الثاعر لخص القصة من خلال تسريع مشهد النص السردي

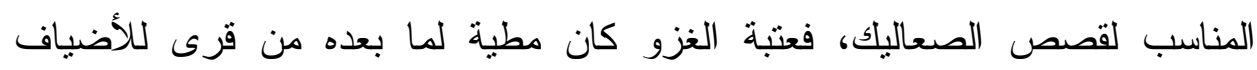
الصعاليك.

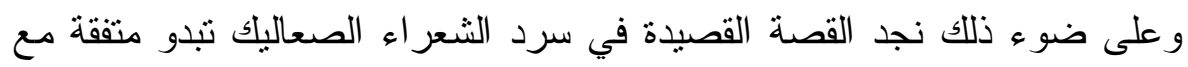
ما يشكل ملامح النتيجة، نتيجة قرى الصعاليك الضعفاء، فنجدهم يصفون تفاصيل

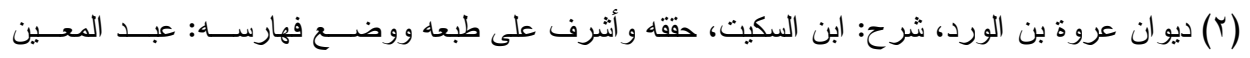

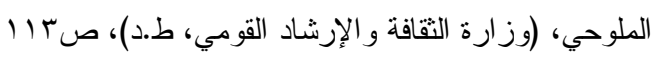


مغامر اتهم ثم ينتهون إلى ذكر الكرم و العطاء، مما يجعل وصفهم للكرم تلخيصًا لما تم التعريج عليه من أحداث المغامرة.

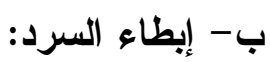

إيطاء السرد نقيض للسرعة، فالثاعر يقف عن تفاصيل ويسرع في تفاصيل، "ففي

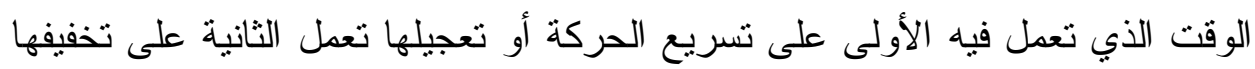

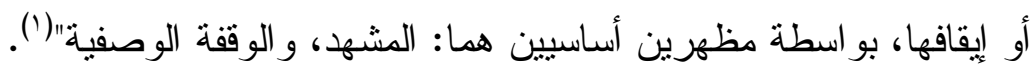

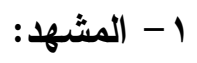

يتضح مفهوم المشهد فيما يعرف بأنه" تعبير مباشر ونقل حي للأحداث و الوقائع

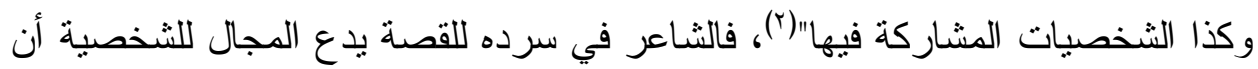

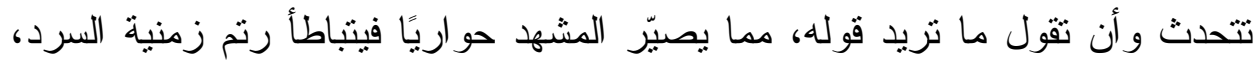

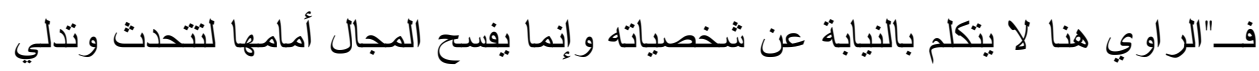

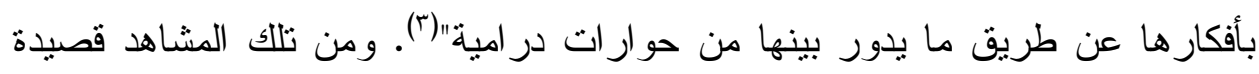

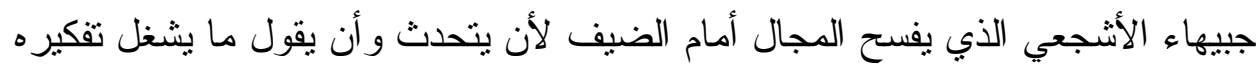

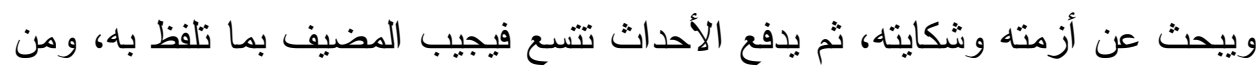
ذلك قوله (๕)

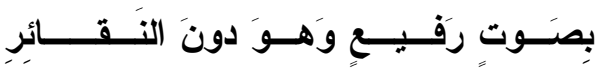

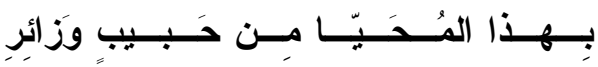

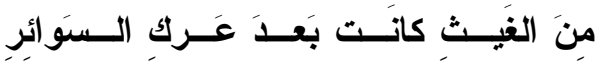

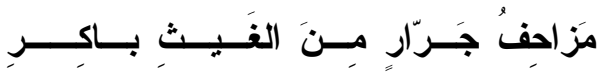

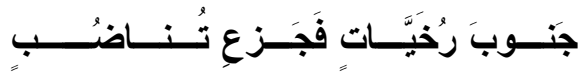

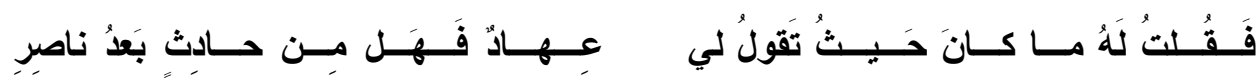

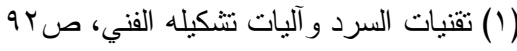

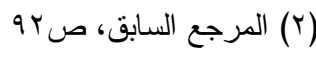

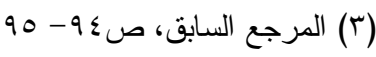

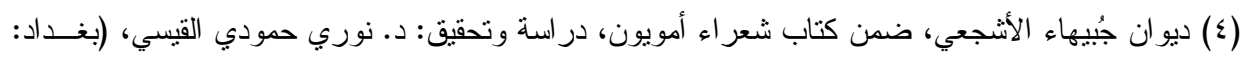

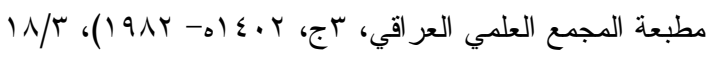




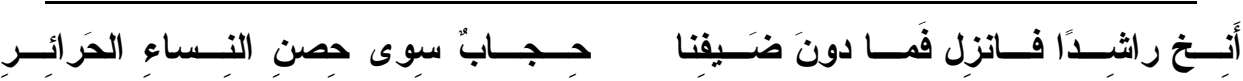

فالثاعر يمنح النص رنم الإبطاء من خلال مساحة الحوار التي تتتل بين الضيف

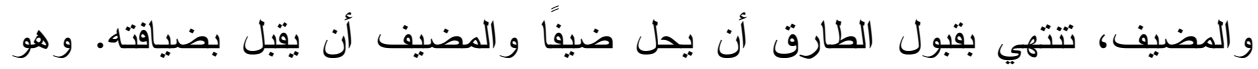

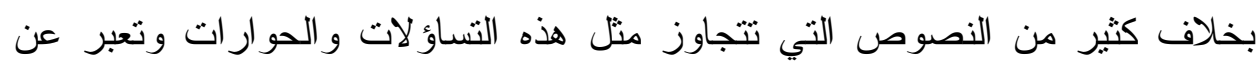

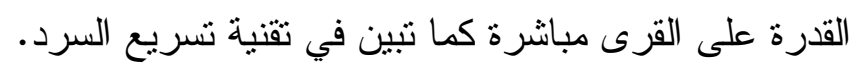

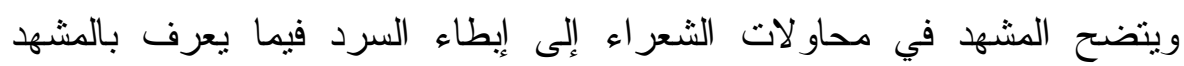

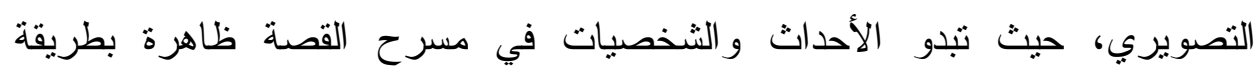
تصويرية، يتمكن السارد الثاعر من وصف الأحداث بطريقة ناقلة لا تبدو هناك مساحة

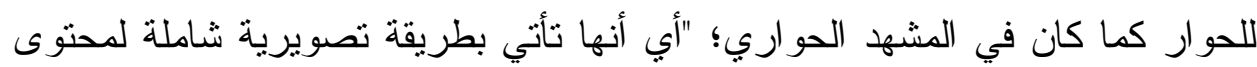

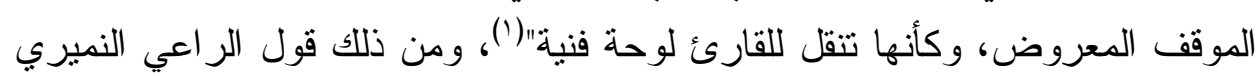
وهو يصف نار القرى (r) :

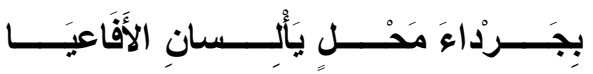

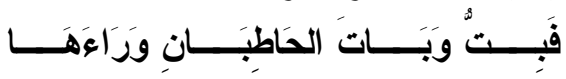

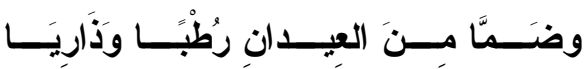

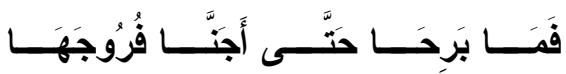

فالثاعر يصف موقف إثتعال نار الضيافة من خلال إثعالها مع الحاطبين، ثم لا يكتفي بإبرازها و إنتعالها، و إنما يمد من مشهد السرد حين يظهر مدّ النار بالعيدان

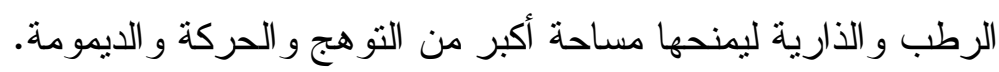

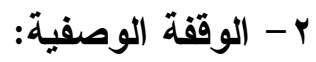

هي التقنية التي تعتمد على الوصف في البناء السردي، فــ" كثثر ما يكون المسار

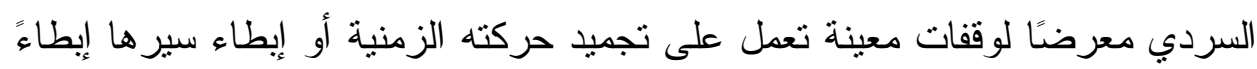

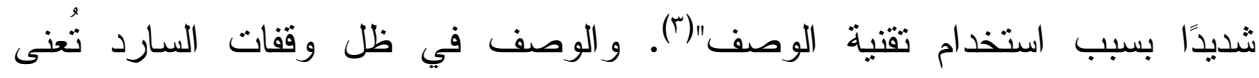
بـ" الخطاب الذي يسم كل ما هو موجود فيعطيه تميزه الخاص وتفرده داخل نسق فئ فئن

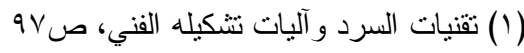

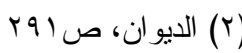

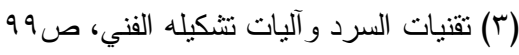


الموجودات المشابهة له أو المختلفة عنه"('). ومهام الوقفة الوصفية أنها تقدم تفسيرات

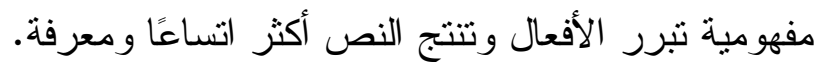
وفي البناء السردي للقصائد كثيرًا ما يقف الثعر اء حول الثخاء ومعرهيات، أو حول وصف أداوت الضيافة، أو وصف الزمان والمكان، مما يظهر القصة في تسلسل بطيء، ومما يمنل الوقفة الوصفية في شخصية الضيف قول عمرو بن الأهنم الذي وبي يسرد مجموعة من الوصوف التي تشرف على مد القارئ بمجموعة من المعلومات التي تصف شخصيته (r) :

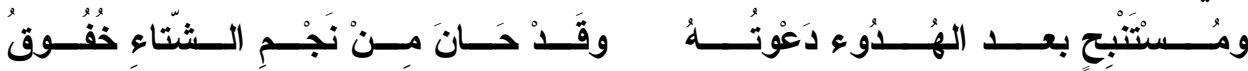

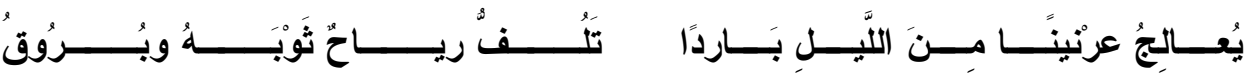

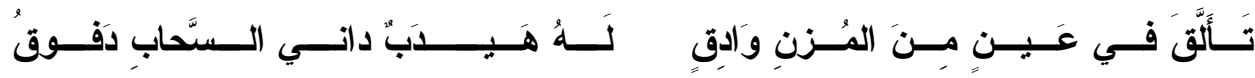

وتبدو الوقفات الوصفية ظاهرة في وصف الزمان الذي يلف مشهد الضيافة، وما يحكي منل هذه التقنية إحدى قصائد مرة بن محكان الذي يبدأ تتسلسل أحداث الحكاية عنده في موقف المحاورة مع زوجته، وهو في مشهد المحاورة يتوقف السرد لديه

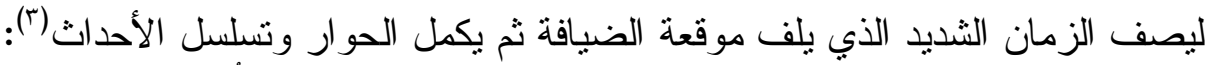

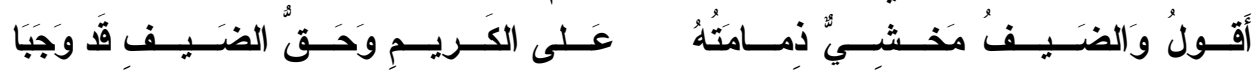

(1) وظيفة الوصف في الرواية، عبد اللطيف محفوظ، (الدار البيــضاء: دار اليـسر للنـشر و التوزيــ، طا،

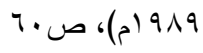

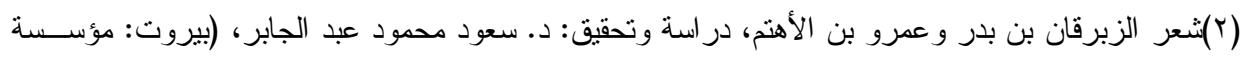

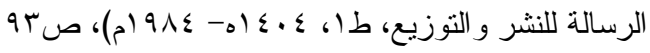

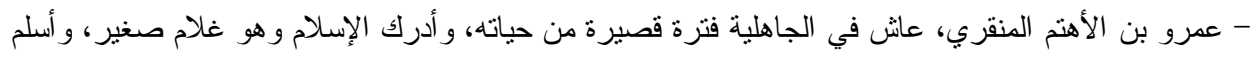

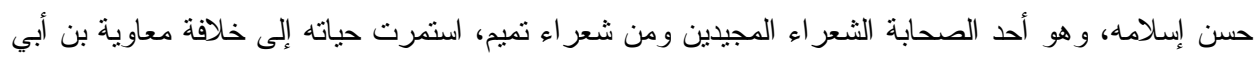

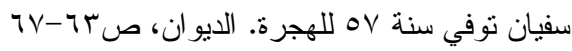

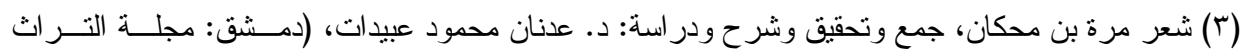

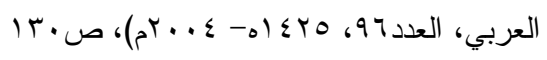

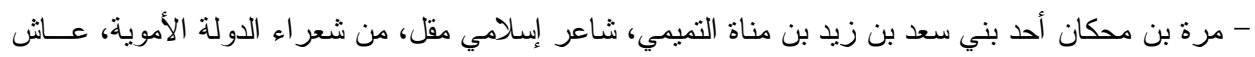

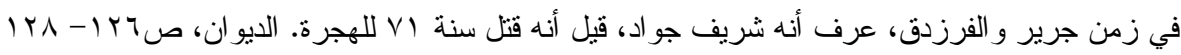




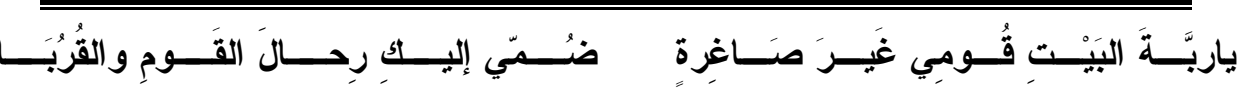

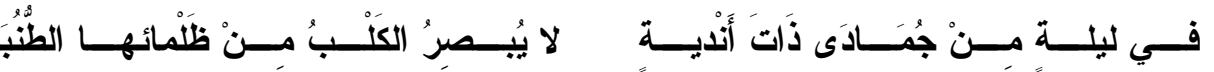

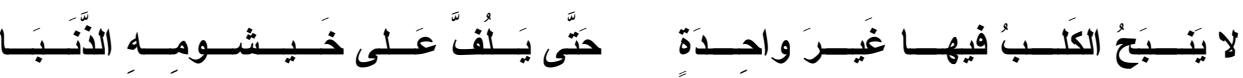

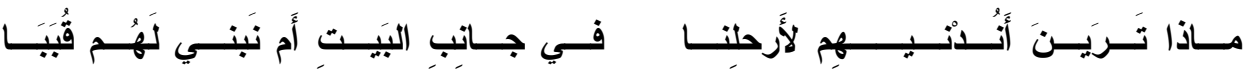
و استعمال الوقفة التصويرية يختلف من شاعر إلى شاعر ومن قصيدة إلى أخرى، فبعض القصائد يهنم بالضيف و البعض الآخر يهتم بالمضيف، و البعض الآخر يهنم بالأدوات، وبعضها في وصف الزمان و المكان. 
الخاتمة:

نلحظ أن الشعر اء استثروا قصيدة الضيافة في توظيف عناصر البناء السردي

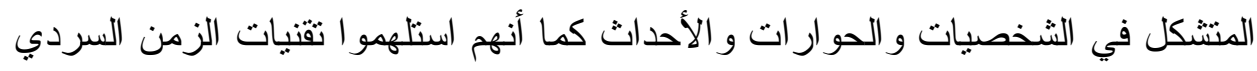
وذلك في الترتيب الزمني الذي يعتمد على الاسترجاع و الاسنباق، و المدة الزمنية التي

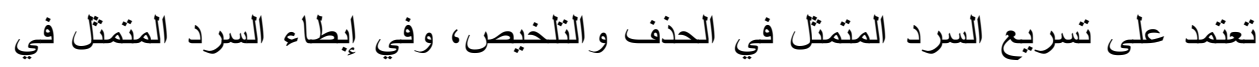
المشهخ و الوقفة التصويرية. و المتأمل يجد الثاعر العربي كان متقبلًا ومتمثنًا للمعرفة الحديثة عبر و عيه العميق

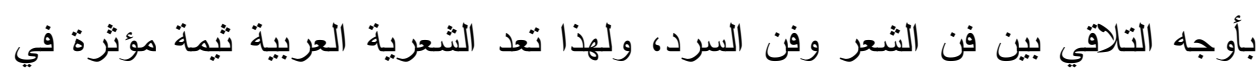

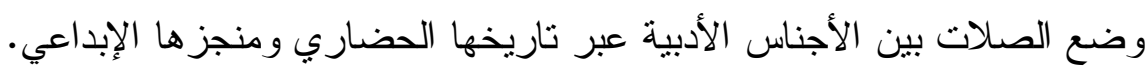


1- الكتابة عبر النوعية، إدوارد الخر اط، (القاهرة: دار شرقيات، ط. د، ع99 19).

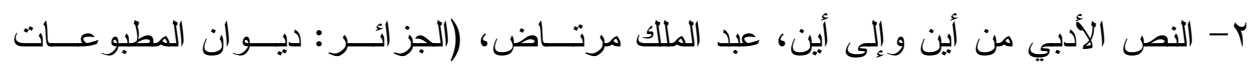

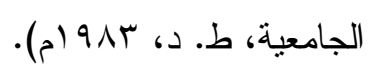

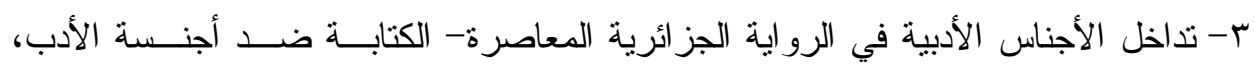

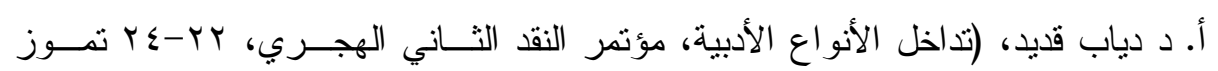

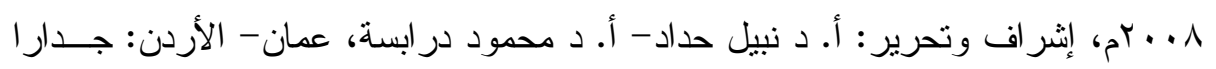

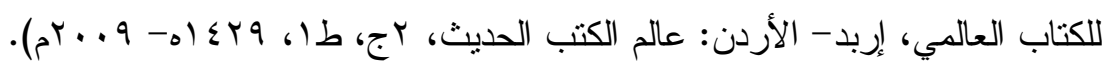

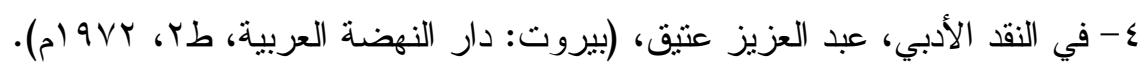

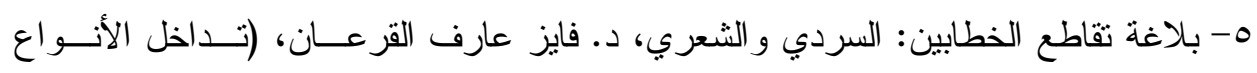

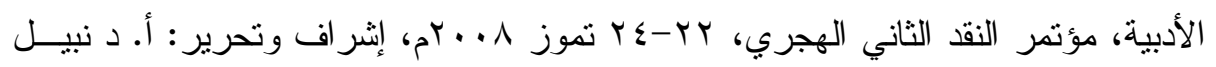

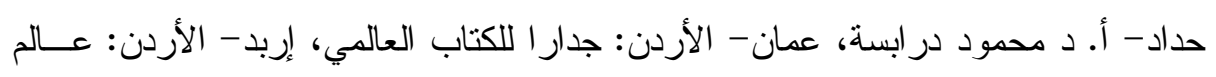

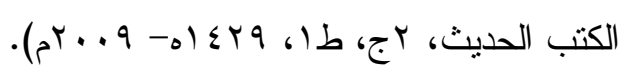

ج-بناء الثعر على السرد في نماذج من الشعر العربي الحديث، د. أحمد جوه، (تداخل الأنواع

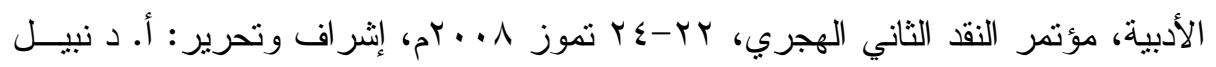

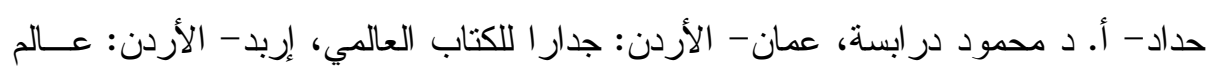

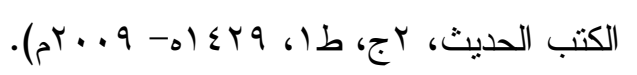

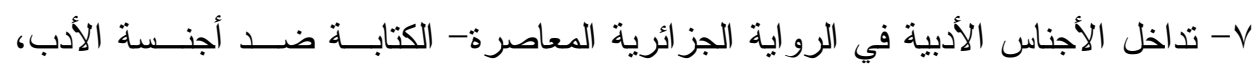

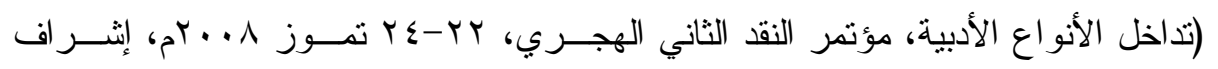

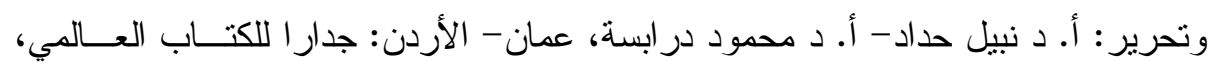

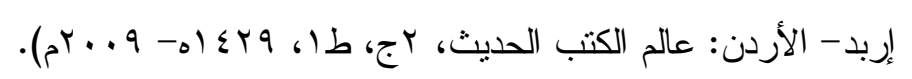

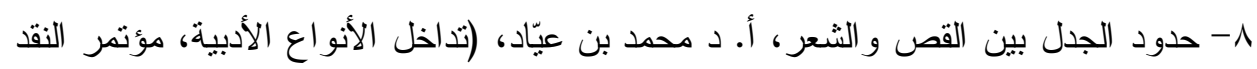

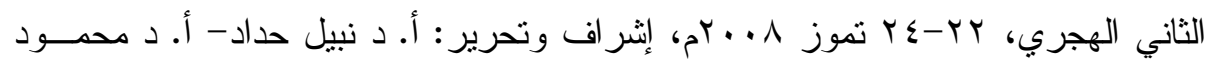

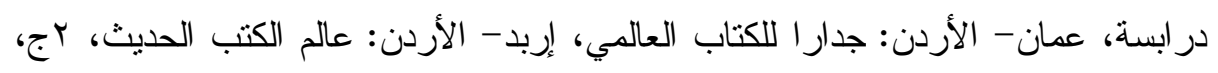

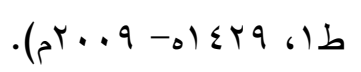

9- الوجيز في دراسة القصص، لين أولتيرند، ترجمة: عبد الجبــار المطلبــي، (بغــداد: دار

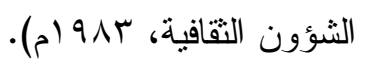


• 1- بنية الخطاب السردي في القصة القصبرة، د. هشام ميرغني، (الخرطوم: شركة مطــابع

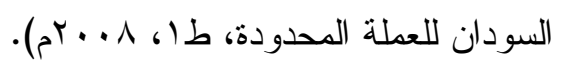

1 ا - ديوان الأبيرد الرياحي، ضمن كتاب شعر اء أمويون، دراسة وتحقيق: د. نوري حمودي طودي

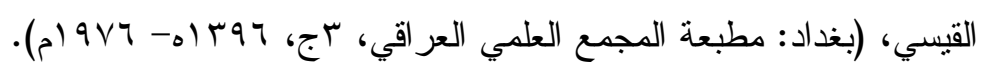

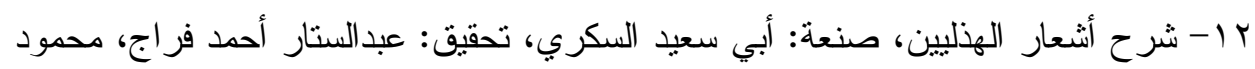

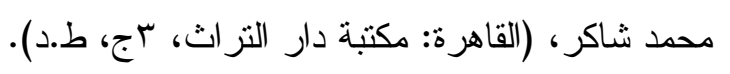

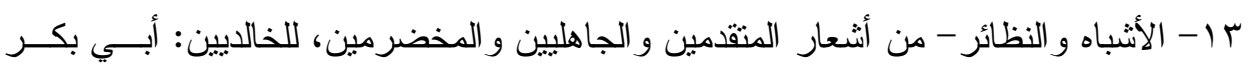

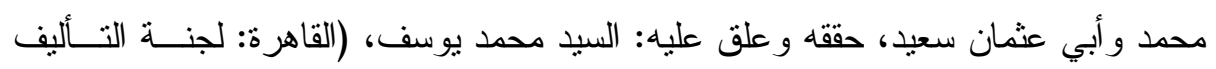

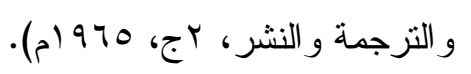

ع ا - الثخصية و البيئة في القصة القصيرة، ثابت ملكاوي، (الإمارات: أبحاث الملتقى الثـاني

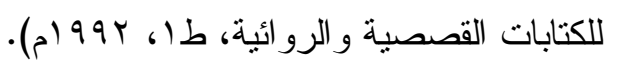

ه بنية النص السردي من منظور النقد الأدبي، د. حميد محمد لحمداني، (بيروت: المركـز

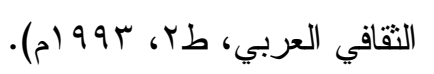

7 ا - مقو لات السرد الأدبي، تزفتان تودوروف، ترجمة: الحسين سحبان - فؤاد الصفا، (آفــاق

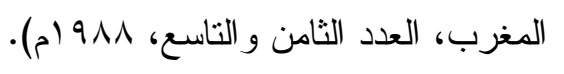

V V - تقنيات السرد و آليات نتكيله الفني- در اسة نقدية، د. نفلة حسن العـزي، (عثّــان: دار

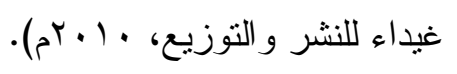

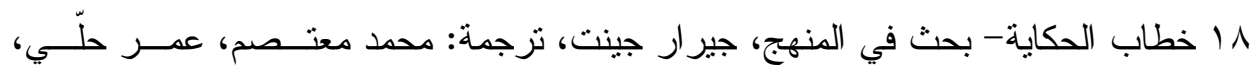

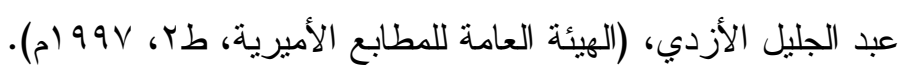

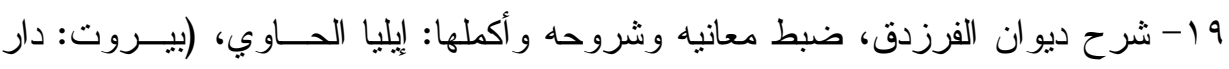

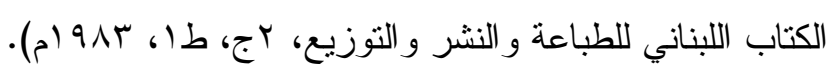

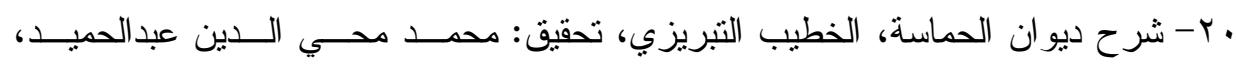

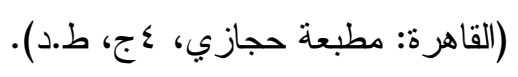

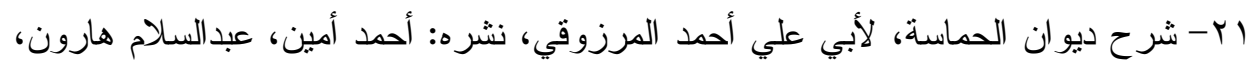

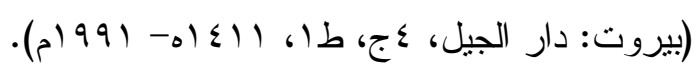

Y Y- ديو ان القطامي، تحقيق ودر اسة: محمود الربيعي، (الهيئة المــصرية العامــة للكتــاب،

$$
\left.\cdot()^{\prime} \cdot \cdot\right)
$$


بr- الحماسة البصرية، صدر الدين الحسن بن علي البـصري، تحقيـق وشــرح ودر اســة:

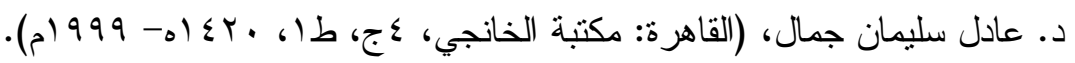

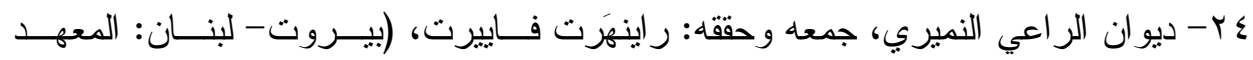

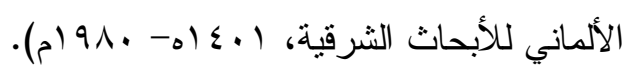

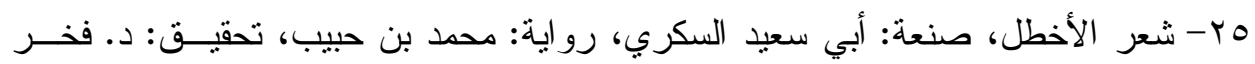

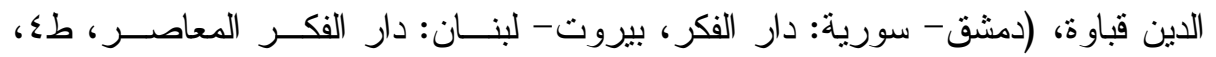
.) (م) 997

جr- در اسات في القصة القصيرة، يوسف الثناروني، (دمثق: دار طلاس، ط ا، 919 (ام).

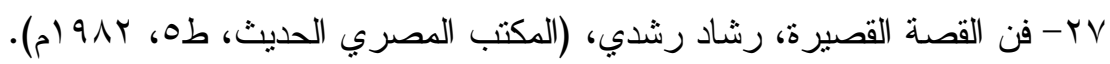

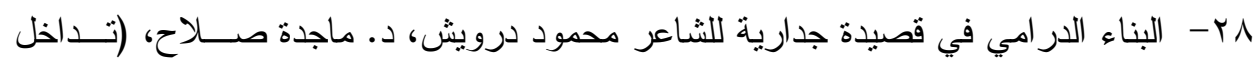

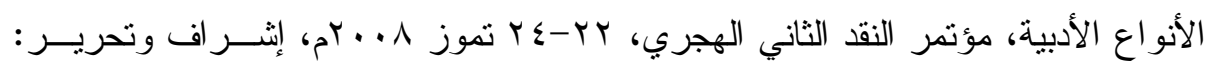

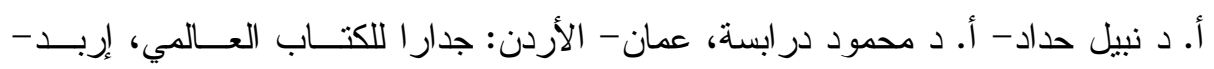

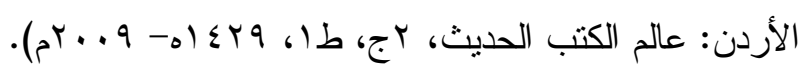

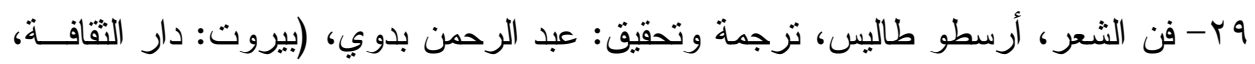

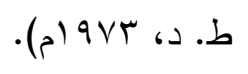

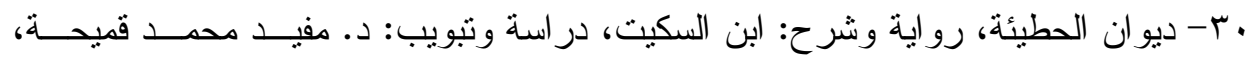

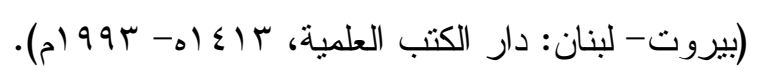

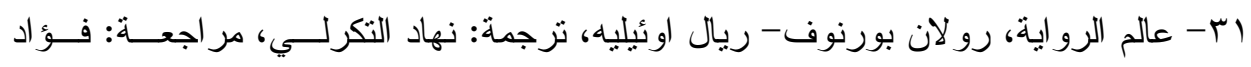

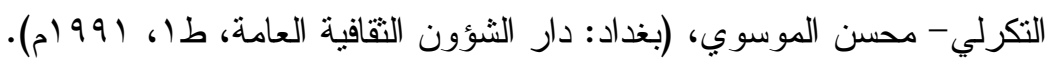

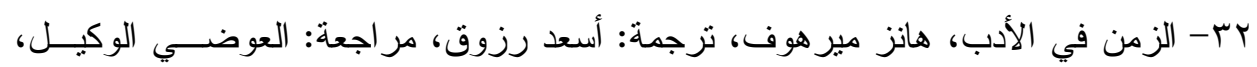

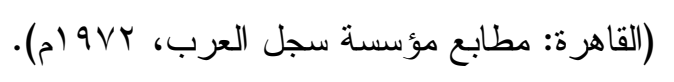

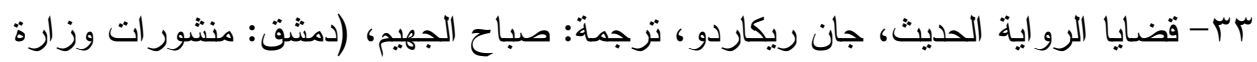

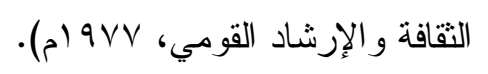

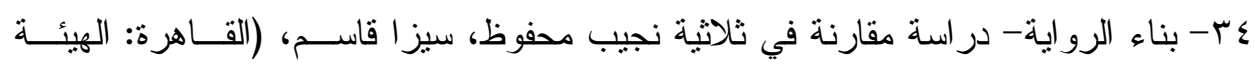

$$
\text { المصرية العامة للكتاب، ع ـ . بم). }
$$

هب- شعر إبر اهيم بن هرمة القرشي، تحقيق: محمد نفاع، حسين عطوان، (دمشق: مطبو عات

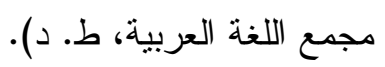


جr- شعر منصور النمري، جمعه وحققه: الطيب العشاش، (دمثق: دار المعارف للطباعــة،

$$
\text { . (م) (91)-0) } 190.1
$$

VV سالم الكرنكوي، عبدالرحمن يحيى اليماني، (بيروت- دار النهضة الحديثة، آمج، ط. د).

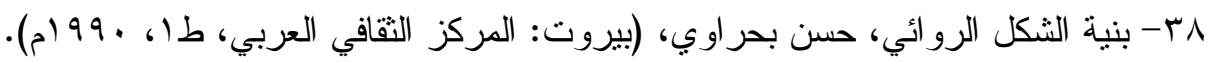

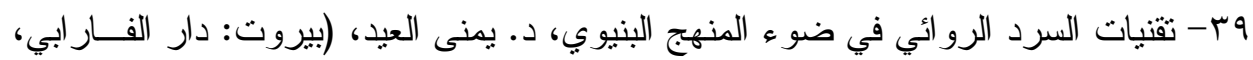

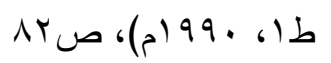

• ع- في السرد- دراسات نطبيقية، عبد الوهاب الرقيق، (تونس: دار محمد علــي الحـامي،

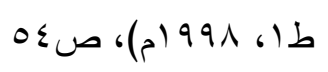

اء- شعر العُجير الستّلولي، صنعة: محمد نايف الديلمي، (مجلة المورد، بغـــداد: دار الحريــة

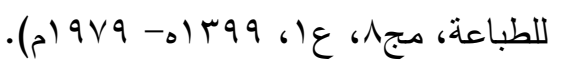

r乏- أثنعار اللصوص وأخبار هم، جمع وتحقيق: عبد المعين الملوحي، (بيروت: منـشور ات

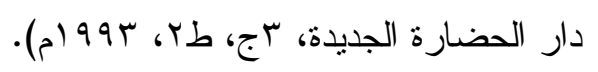

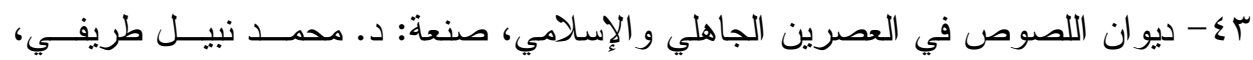

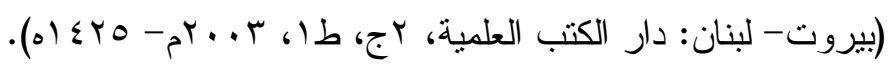

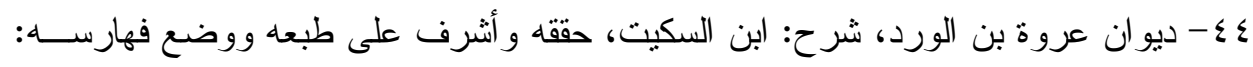

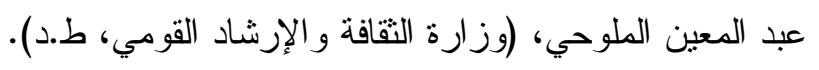

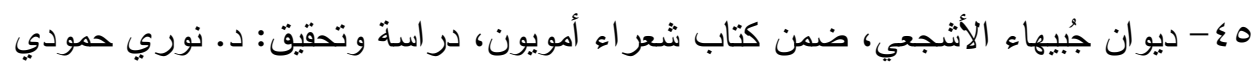

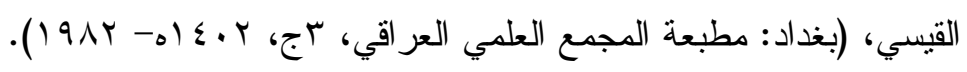

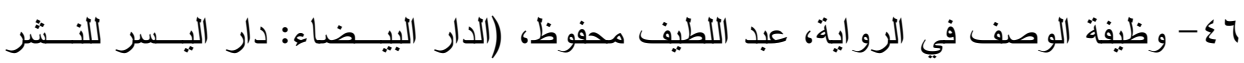

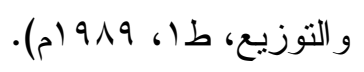

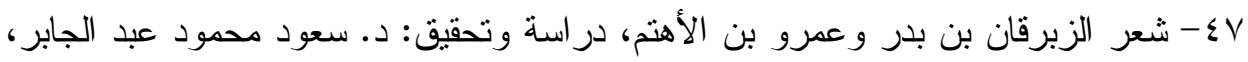

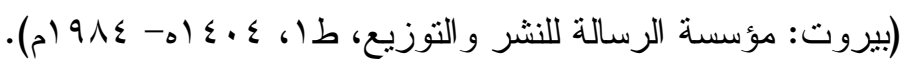


